DNI $-3 \div 153$

DES: 006681

RADIOLABELED RED BLOOD CELLS: STATUS, PROBLEMS, AND PROSPECTS

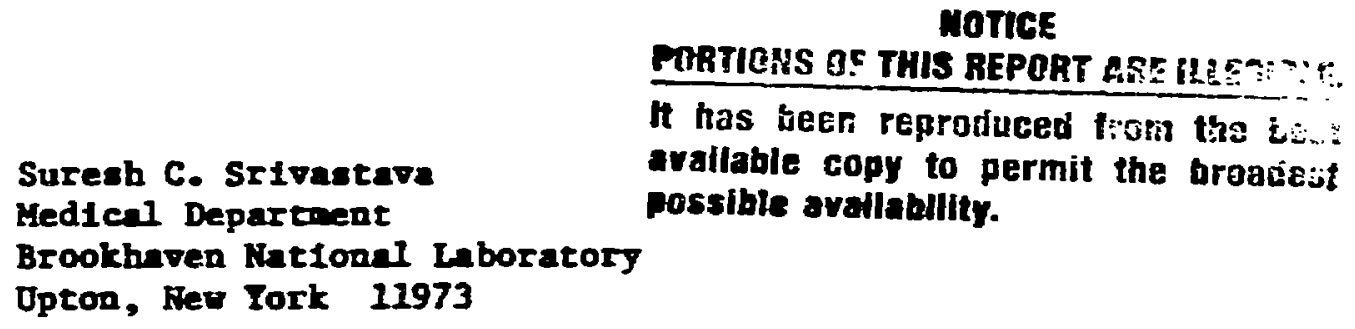

INTRODUCTION

of the various cellular blood elevents, red cells (RBC) are: (1) wost abundant; (2) eany to separate and handle; (3) less surcepttble to damage from physical or chenteal anipulations; (4) not as dependent on energy and nutritional requitemente in vitro, and (5) more anenable to labeling with radionuclides due to the avallability of a vartety of sellular transport mechaniews and of heroglobin within, that $1 \mathrm{~s}$ rich in active setal binding sites. Consequently, red cells have served as simple, convenient, and useful modela for the study of anong other things, ceilular transport phenowena and membrane structure and functionl, 2 .

Red cells dispersed in plasma are not truly living cells. They are composed of water (65z), hewoglobin (32Z), and otber protein and lipid stroma (37), and possess properties (clrculer, non-nucleated biconcave discs; narked elasticity, etc.) that are ideally sulted for their functions to rapidly absorb oxygen in the lungs, to pasa through sanlleat capillaries without danage, and to give up $\mathrm{O}_{2}$ rapidly to the tissues. The average $\mathrm{BBC}$ count is about $5 \times 10^{9}$ per $\mathrm{ml}$ of blood and their aurface area approxinately $3 \times 10^{3} \mathrm{sq.m}$. (or 1500 tines the body auface area).. Nornal red cells have a Iife span of 110-120 days; the usual rate of replacenent is 0.8-17 per day. Heroglobin, the nost inportant component of the red cell, renains atable and does not undergo degradation or resguthesle during the life of the cell. The hemoglobla wolecule contains four hese and globin wolecules, and has an average nolecular wefght of 68000 . The ferrous iron in here is bound covalentis to the four porphyrin nitrogen atons. The fifth bond is to the Inldazole nitrogen of the hiatidine of globla, and tbe airth is in a reversible binding to oxygen.

\title{
DISCLAIMER
}

This report was prepared as an account of work sponsored by an agency of the United States Government. Neither the United States Government nor any agency thereof, nor any of their employees, makes any warranty, express or implied, or assumes any legal liability or responsibility for the accuracy, completeness, or usefulness of any information, apparatus, product, or process disclosed, or represents that its use would not infringe privately owned rights. Reference herein to any specific commercial product, process, or service by trade name, trademark, manufacturer, or otherwise does not necessarily constitute or imply its endorsement, recommendation, or favoring by the United States Government or any agency thereof. The views and opinions of authors expressed herein do not necessarily state or reflect those of the United States Government or any agency thereof.

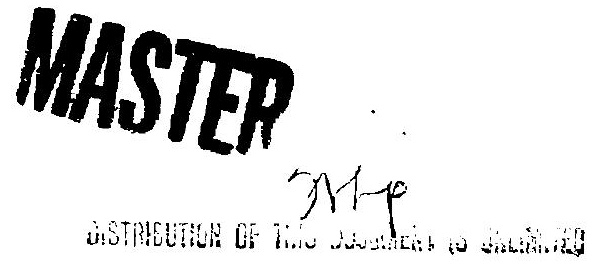


Radionctive labels that have been utilized for red cells noetly bind to hemglobin but can also bind to other intracellular components as well as to curface protelns on the nabrane. The dealrable properties of an 1deal radionuclide label, especially for diagnostic nuclear nedicine applications, are se follows: (1) the radionuclide can be incorporated whout altering the physical or blochenteal properties of the cella and thefi 1n-vivo function; (11) the radionuclide should have a gama energy ewission in high soundance sultable for langing, a nintwe of cell-danaging low-energy Auger and conversion electrons, and a phyoleal half-life natched to the tine frame of reasonably itable $i r . j u$ as well as in $\nabla 1 v 0$, and once incorporated into

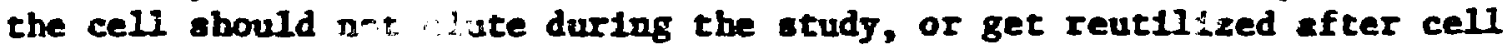
destruction, and ( $D D)$ the radionuclide should have little or no particulate emtssion in order to mintalze patient radietion dose.

Radionuclidic Iabels for red cells can be difided Into two wafn categorles - cohort or pulse labels, and randon labels. The cobort labels bind to arrow precursors but not to cells already in circulation. Labeled cells of uniform age appear in the circulation after a few iays and thus cohort labels are useful for the study of cell production rate and survival. The Iandor labels are incorporated into circulating cells of all ages and the labeling procese is usully carried out in vitro on amall sample of venous blood. Except for sone earlier atudies on ferrokfnetics and red cell production, etc., using Iron radionuclides, nost of the red ceIl labels developed so far and those in predontnant use at the present time Involve randon labeling and exploy technetiur-99k, chromim-51, Ind1w-111, and gall1w-68, roughly in that order. A liating of the various labels appears in Table 1. Also included 18 inforwation on the compound used and whether the labeling is carried out in vivo or in vitro. The various diagnostic applications of randonly used labels are shown in Table 2. The extent of usefulneas depends, of course, on the properties of the label such as the half-life, decay node, and In-vivo stabllity, etc. Inbeled cella con be used for red cell survival measurements when the half-1ife of the radionuclide 18 oufficiently long. The major portion of this article wil deal with randon labels; only a brief discussion will be provided of the cohort labele.

\section{COBORT LABELS}

As mentioned above, the use of radionuclidic labels that get incorpirated into bone arrov red cell precursore over a linited tine pertod-produces a labeled cobort of celle of approstmately Identical age. In an Ideal attuation, 2957 of the label would eppear in the circulation within 4-5 daye and the amount of the label in blood would remaln constant until removed fron the circulation due to aging of the cells, In a sigmold fashion ${ }^{3}$. 
Sush an 1deal stuation is not obtafned with the we of eitber labeled glycine or radio1ron. Reverthelese, these tracern have providad useful

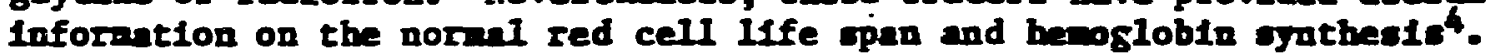
The most important application of radiolron hil been in ferrokinetic measurements 5 . Its use perifta a complete functional malyals of the red cells at all stages, for exseple, quentification of erythropoelala and Iffe span, identification and evaluation of the altes of red-cell production and destruction, and quantitative deterndation of blood lose. In combination with $51_{C r}$, radiolion can be uaed for meanuring, stmultaneoualy, both red-cell production and destruction. Although it 1 sot sultable for routine studies, the use of $\mathrm{DF}^{32 \mathrm{P}}$ (d11soprops 1 fluorophosphate) has been advocated in spectal Investigation, both as a cobort and a randon label ${ }^{9}, 10$.

RANDOM LABELS

Randon labeling of huan erythrocytes is used wore wdely than cohort labeling, andily because it involves procedures that are easier to perform In a clinical aetting. In addition, and perhaps are importantly, radionuclides that possess farorable chenical and phyaical properties and that are available for research and elinteal use, label red cells randonly.

1. Chronium-51. Chrontur-51 labeling of red cells 1s the wot popular techique at the present tine for the measurenent of red cell ilfe span. Gray and Sterling in 1950 showed that $51 \mathrm{Cr}$ 1n the form of chrouste could be used for effectively tagging red cells of various opectes, inciuding anil. Their observations led to the rapid developwent of $51_{C r} R B C$ for measuring red cell suroival in human subjects 12,13. Two problens are however, associated with this technique. The chromium label leaks fron the red cells and this leakage, normally 17 per day, is often variable. Secondly, there appears to be an uneven labeling of cells depending on the age of the RBC and also on the nature of the henoglobin 1tself. Appropriate corrections can be made to account for these problers and rellable results can be obtained.

The chronium 1n the hexavalent form penetrates the red cell nembrane and attaches to the globin part of the hemogiobin nolecule. The predominant attachwent is to the beta chatn of globin14. The cationic trivalent for of chroutu does not cross the menbrane but binds to proteins in the plasm. Chronim-5l red cell survival curves can be erroneous in altuations where cells contain abnormal hemoglobin and eapectally when greater or lesser anounts of the beta globin chain are present. The half-Ilfe of $51_{\mathrm{Cr}}$ of 27.7 days is conventent for clinical studies although not ideal. Game raye of $0.32 \mathrm{HeV}$ energy are enttted in 9.87 abundance and this allowe for seasurenents using a sodiun lodide well counter. In addition, this gama enission 18 useful when double 1sotope studies axe carried out exploying the higher energy ( 1.10 and 1.29 ieV) 1 ron-59, with appropriate crossover corrections ${ }^{8}$. 
The binding of ${ }^{51} \mathrm{Cr}$ to red cella in Fitro ia rapid and is $>907$ conplete within 30 ain at roon temperature in ACD solution. The label 18 quite firm and resista repeated washing of the cells or dialysis. Factora thet decrease efficlency of binding ares (1) prior contact of 51Cr wth ACD for periods exceeding an hour before addition of RBC; (11) incresalng the pH of ACD solution or autoclaving it; (111) presence of calcic lons, and (1V) prolonged exposure of the $51_{\text {Cr-ACD nixturea to }}$ strong light. Ery throcy tes can be damaged by excess netallic chromiun (50 $\mathrm{\mu g} / \mathrm{ml} \mathrm{RBC})$, and this was a limitation in the early work because of the low specific actirity of 51Cr arallable at that tine. Alterations in the RBC are noticed even at 5 Hg chroriw per al; howerer, auch changes, mosty enzymatic, do not produce a significant effect on red cell survital. High specific activity 5lCr, presently arailable, pernits the use of 1 ess than $0.1 \mathrm{\mu g}$ chromium per al blood, thus allowing for the use of nore actirity with minimal damage to the cells.

The labeling procedure, briefly, is a follows. Approximately 16-20 al of blood la withdrawn from the patient and added to a sterile multinjection bottle containing $4-5$ ml of ACD solution (comercially arallable, containing, per al, $13.2 \mathrm{mg}$ dextrose, $25 \mathrm{mg}$ anhydrous sodium citrate and $8 \mathrm{mg}$ anhydrous citric acid). PIfty to $100 \mathrm{\mu Ci}$ of $5 \mathrm{ICr}_{\mathrm{Cs}}$ sodium chromate is then added and the mixture allowed to incubate for 30 min at roon temperature with intermittent gentle wirling. Fifty ascorbic acid ( $0.2 \mathrm{al}$ of a $250 \mathrm{gg} / \mathrm{ml}$ solution) is added next to stop the tagging. The unlabeled $5 \mathrm{I}_{\mathrm{Cr}}$ can be removed by centrifuging and discarding the aupernatant solution and injecting the saline-resuspended $\mathrm{RBC}$, or the mixture infected as such and allowance made for non cell-bound $51 \mathrm{Cr}$ in the calculations. The labeling efficlency should be determined on an aliquot of the well-mixed suspension in the latter case. Appropriate standarda, properly diluted, are necessary for counting and comparing purposes.

The addition of ascorbic acid was proposed by Read and coworkersl3 In order to reduce the unbound chronate to trivalent chromiun and thus prevent further labeling of the cells before or after infection ( $\mathrm{Cr}^{3+}$ does not cross the cell membrane). This obriates the need for washing the cells prior to injection. By performing external body measurements for 5lCr activity uaing a acintillation detector, the clinical usefulness of red cell survival studies can be enhanced further. For exasple, the potential aftes of red cell sequestration in hemolytic atates can thus be deternined.

Damsing the cell. (chemically ${ }^{15}, 16$ or by heat treatnent 17,18 ) following (or during) the $5 I_{C r}$ labeling operation protides an agent suitable for the scaming of the spleen or for the study of aplenic function. In early work, ant1-D antibodies were also used to induce splenic trapping of the cells 18,19 . The procedure for heat damaging the 
cells was developed 1 ater 17 and to alnost exeluetvels used at the present tine. The degree of heating $\left(49^{\circ} \mathrm{C}, 15 \mathrm{in}\right)$ bowever, has to be controlied very carefully since ang exceseste dange to the cello would result in hepatic as well as oplenic sequestration of the activts.

2. Indiw-and GaIllum-Labeled RBC. Cercaln radionuclides of indiw and gallim (e.g. $111 \mathrm{In},{ }^{113 .} \mathrm{In}, 67 \mathrm{Ga}, 68 \mathrm{Ga}$ ) posees favorable properties for application in dignonelc nuclear nedicine. Cell labeling wth these nuclides 18 andy carried out using a procellure developed by Thakur et al.20,21 that exploja the 8-hydroxgquinoline (oxdne) chelate of these elewents. Indlu-oxtne labeled leukocytes and platelete conetitute an important class of radlopharmeeuticals and the1r value in clinical nuclear nedicine 18 already well established 22,23 . Labeling of erythrocytes has also been carried out using the oxtne chelates of indiw and gallium $20,21,24-26$. The use of an acetylacetone (acac) complex of Indiun for labeling RBC and other cello has ales been advocated 27-29. It 1s clalwed that the nethod of preparation of the acac complex 18 sinple and that the labeling procedure ang be less danaging to the cells.

Indium-oxine labeled red cells have been used in the detection of Interaittent G.I. bleeding in antmal wodels as well as in man $26,30,31$. The typical labeling procedure is as follow. Approxinately 10 ml of venous blood 18 drawn into a syinge containing about 60 untts of heparin, transferred to a round botton tube, and centrifuged for 5 min at 1000-1500 G. The supernatant plasma and buffy coat are removed and the red cells washed twice with 5 wl of normal ealine. The cells are then resuspended into 2 volumes of saline, Incubated with $0.5-2$ mC1 of 111 In-oxine complex for $15 \mathrm{~min}$, and waghed twice with saline. The labeling efficiency generally is in the order of $90 \pm 57$. The cells are mixed with autologous plasma and injected intravenously. If the III In-orine complex 18 not comerctally avallable, it can be prepared in a typical case by the addition of 50 1:8 oxtne to 1 nC1 carrier-free Indium-111 chloride adjusted to $\mathrm{pH} 5.5$ wth $0.3 \mathrm{H}$ acetate buffer, extracting into an equal volume of chloroform, evaporating the chloroform layer to dryness, and finally dissolving the residue in $50 \mu 1$ propylene glycol and diluting with $150 \mathrm{ul}$ saline. It is often difficult to locate the source of Intermittent G.I. bleeding by the usual procedures such as anglography, endoncopy, or scaming with 99tr-labeled oulfur collold or red cells. These wethods show hemorrhage only at the time of bleeding. A tracer that would remain for a long enough pertod in the circulation to permit repeat inaging is preferable, and 111 In-RBC fulfills this requirement. The half-ilfe of 67 hr and its abudant 173-and 247-keV gama eniastons ake indium-111 Ideal for this purpose. A major difadvantage io the relatively faster In-vivo elution of the label - approxinntely 72 per day 1 a one reported case in man 30 , and wuch higher in antwals. In rabbits 26,702 of the

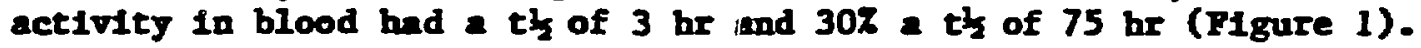
Urine excretion reached a maximum of 2.57 per al at 60-150 minutes; it was very slow thereafter up to $72 \mathrm{ln}$ (PIgure 2). It 18 claimed that despite the elution of the label, rascular inaging can be performed 
for as long as $120 \mathrm{hr}$ and bleeding In the G.I. tract detected up to 48 hr after injection30. A wethod to produce IIIIn-RBC with higher in-riro ctability is highis desirable.

Lebeling 5 lelds of $>907$ hare been reported in the $68_{\mathrm{Ge}-o x i n e}$ labeling of red cells 24 . The oxine conplox 1 s prepared by a aethod rery aldilar to that used for preparing 111 In-oxine. If the $68_{\mathrm{Ge}} / 68_{\mathrm{Ge}}$ generator provides 68-EDT, the complex has to be disaociated following the usual procedures 32 , before preparing the oxine chelate.

Gelliw-68-RBC were shown to hold promise for inaging blood poola using positron tomograph; the results were found to compare farorably with those obtalned uaing $1 I_{\text {co as a label }}{ }^{24}$.

A net: approach was described recently for labeling the surface of red cells with $57 \mathrm{Ga}^{33}$. The washed cells are first treated with tannic acid and then incubated with pH $767 \mathrm{Ga}$ chloride. The incorporation of gallio was reported to be $>90 Z$ In $15 \mathrm{aln}$ and the 1n-titro stabllity of the label wan clalmed to be good. Further work will be necessary to demonstrate the usefulnesa of this approach for in-rivo atudies.

The use of ${ }^{111}$ In-tropolone complex for labeling platelets was described in a recent report34. The possibllity of labeling other cells with this complex was also suggested. Both oxine and tropolone form neutral chelates with indiw and galliw with conparable stability constants and the cell labeling mechanisws of the wo nay indeed be rery similar.

3. Hiscellaneous Labels. Red cells have been labeled both in ritro and in Vivo (cohort labeling) with rarious other compounds including $11 \mathrm{CO}^{35}$ $42 \mathrm{KCl}^{36}, 37, \mathrm{Na}_{2} \mathrm{H}^{32} \mathrm{PO}_{4} 37,125 \mathrm{I}$ - or $131_{\mathrm{I}} \mathrm{P}$-1odobenzeneaul fonamide $38, I_{31}$ lodnpheny 1 by droxy lamine $39,5 \overline{F e}^{40}$ and 75 se gelenome thionine 41 . Any sighifieknt use of most of these has not resulted due to many obrious reasons.

Carbon monoxide which competes with oxygen to form carboxy hemoglobin was used (by Inhalation) in one of the earlier methods for measuring blood rolune with reasonable accuracy. Carbon-11, a positron emitter with a 20 min half-1ife has been used recently for blood rolume reasurementa. The reaulta are $5-10$ z higher than with $5 \mathrm{C}_{\mathrm{Cr}}$. Nevertheless, II Co could prove valuable for conditions where minimum radiation is ciesirable, and repeat blood rolume atudies are necessary. Howerer, is cyclotron has to be avallable on-site and this imposes severe restictions on the widespread use of ${ }^{11} \mathrm{co}$.

Based on rarious blochemical and kinetic considerations, radiolron 1. the beat nuelide for localizing exy thropoelats. Imaging of 59 Fe in good resolution is extremely difficult because of the high gaman energies of 1.10 and $1.29 \mathrm{MeV}$. Iroh-52, which 18 not routinely arallable, is a good candidate, although ita short half-11fe of 8.3 hr and annihflation radiation of $511 \mathrm{keV}$ make $1 \mathrm{t}$ less than ideal. 
An Interesting new nethod for labeling rad cella using the engme-inhtbitor appzoach was described recently 38 , which ang have sone useful applications. In this atudy, radiolodinated p-lodobenzenesulfonamide, a lipophll1c carbonfe anh drase inhibitor was eaploged to label red cell in whols blood rapidly and with high efficiency $(95 \pm 57$ ). In rate after 1.7 . adainfatration, howerer, the

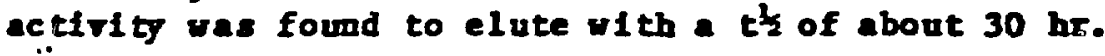

4. Technetiur-99m-Labeled Red Cells. Rapld and convenient $k 1 t$ procedures are presently arallable for labeling red cells with technetion-99a thet provide esaentially quantitative labeling jlelds. The current methodology has resulted from a slow progression of the rarlous ateps involved in the labeling process. Thls has closely paralleled the increase in our understanding of the chemletry of techetim-99n, which in turn has been slow to erolre 42 .

(a) In-vitro methods. Soon after 99"Tc was recognized as the "Ideal" radiotracer for use In nuelear medicine langing applications, efforts were begum to label red cells with this muclide in-ritro. Sereral wockers attempted to label RBC using the comonly arallable form of

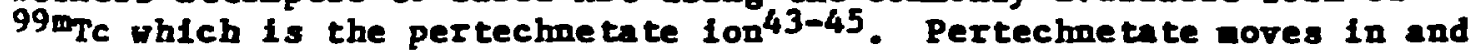
out of the RBC rather freely and cannot be bound firmly to the cella in this chemical form. It was recognized early on that a reduced techetiun species would be necessary to bind irreversibly with hemoglobin or other red cell components, and that reduction of pertechetate within the cell would be a more effectire was of achiering this goal. The use of stamous $\left(\mathrm{Sn}^{2+}\right)$ conpounds to reduce pertechetn te for the purpose of labeling red cells was reported by sereral workers in quick succession $46-51$, and stamous ton 18 still the nost widely used reducing agent in the currently arallable procedures $42,52-54$.

The labeling glelds were inttially limited to the 50-607 range and this made it necessary to separate the unbound 99-Te before injection. Several undeairable washing step. were required. The to earlier schemes invoiring "pretiming" and "post-tinning" of the cells are represented in Figures 3 and 4. These figures describe the various steps that were necessary to obtain good labeling yields and to rewove unbound 99 tre before injection, when necessary.

Host current $k 1 t$ or non-kit procedures now use timing of the cells first, using a suitable tin(II) compound such as py rophosphate, glucoheptonate, DTPA, or cltrate. The videly used Bin kit (approximately $20,000 \mathrm{klts}$ are distributed ammily to investlgators worlduide) consists of the folloning: One Vacutainer reagent tube $100 x$ 15/16 m-10 al capacity, evacuated to drav up to 6 al and contalning a lyophilized preparation of: 2.0 Hg tin, 3.67 ag sodim citrate, 5.50 ng dextrose, and $0.11 \mathrm{mg}$ sodiu chloride (maximu). 
The labeling procedure using this kit is as follows:

\section{S.C. Srivastava}

Labeling Procedure. Use aseptic techniques throughout the procedure.

1. Add 1-3 al of saline 99-Ic pertechnetate to aterile and pyroger-free $1 \mathrm{al}$. Aasay and ctore $1 \dot{\mathrm{n}}$ lead ahield.

2. Draw $4 \mathrm{nl}$ of patient blood Into a heparinized oyinge and add to kete.

3. MII Imediately to dissolve the freeze-dried solids in the blood and gently rotate the tube for five ninutes at roon temperature.

4. Add 1 al of a 4.47 EDTA solution. Drav an equal volwe of air to avold pressure bulldup in the tube.

5. Mix by gentIy Inverting about 5 tines and centrifige the tube upside down 5 ainutes at approx. $1300 \mathrm{G}$.

6. Matntain the tube in the Inverted position to avold disturbing the packed BBC's. UBing a standard $20 \mathrm{~g}$ sterile needle and a 2-3 m sterlle disposable syringe, wthdraw $1.25 \mathrm{ml}$ of RBC's and transfer to the preneasured technetiun prepared in (1).

7. Incubate the techetium-BBC afrture for ten minutes at roon temperature with gentle nixing.

8. Assay and dilute appropriately for injection. Cell separation and Fleld determination at this point consiatently give $98+z$ yields.

9. The described procedure ylelds an excellent agent for blood pool traging and red cell mas studies. Subatitution of the following for Step 7 produces an Ideal splentc agent: Incabate the technet Ium-RBC nixture 15 minutes at $49^{\circ} \mathrm{C}$ with gentle mixing.

EDTA. To prepare the EDTA solution for use with this kit, take any commercially available disodium EDTA cr calcium disodiun EDTA solution for Injection (for example: Endrate, Edetate disodim Injection, USP, I57 solution In water, $\mathrm{pH} 7$, Abbott Laboratories, North Chicago, IL, 60064, USA), and dilute wth sterlle water for Injection to give a final concentration of $4.4 \%$.

Alternately, an Ir-house EDTA preparation can be used if desired. To prepare this, weigh out $4.4 \mathrm{~g}$ disodiun EDTA or calcium disodium EDTA (reagent grade) and dissolve in sterile water for injection or distilled water, under stirring and make up the volume to $100 \mathrm{al}$. Sterilize this Bolution by autoclaving.

Allquots of the sterile $4.4 \mathrm{z}$ EDTA solution (elther in-house or comercial) can be dispensed into a number of individual sterile vials ard stored in the refrigerator for subsequent nse.

The various steps Involved are shown schematicelly in Figure 5. The determination of labeling yield is carried out as followe: 
Draw an aliquot $(0.1-0.5 \mathrm{al})$ of the well-aixed labeled

red-blood-cell suspension into a gringe and add to a tube containing 2 al aaline. Mix briefly and centrifuge liv 5 ain at approx. $1300 \times G$. Withdrav supernatant solution and tranafer to another tube. Hake voluea in both tubes sane with water. Count superantint solution and RBC and calculate the yleld as follows:

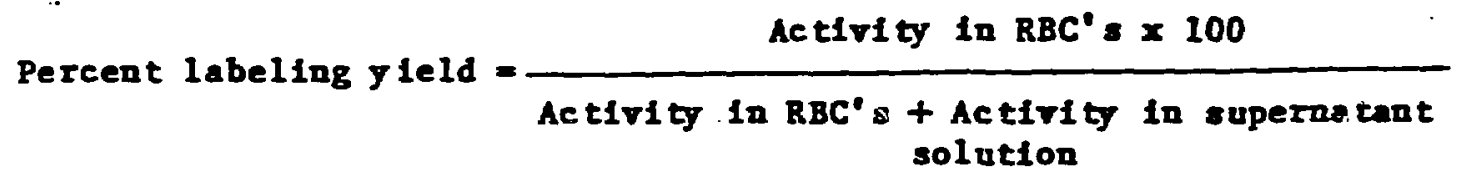

The 99 me activity should be measured in a dose calibrator unless the sample has been allowed to cool down to <I HCI In which case a NaI gama coumter can be used.

The procedure now uses $1 \mathrm{ml}$ of 4.47 EDTA Instead of $6 \mathrm{ml}$ saline (as previously recomended52) after the tinning step prior to centrifugation. This improves the labeling gield and the In-vitro stability of the label as shown in Table 3. The blood clearance curves are shown in Figure 6. These were obtained in an asplenic dog and indicate the EDTA treatment producing a small but significant improvenent in the 1 n-viro stability. 
Red cell mass determinations uaing the BNh $k$ it provide ralues that are In close agreement with those obtained using ${ }^{51} \mathrm{Cr}-\mathrm{RBC}$. The data are shom in Table $4^{64}$. Expertments with double labeled RBC (51Cr labeling followed by labeling same cella with 99me) ahowed (Table 5) that it is the 99 me label thet elutes frov the ceils. and leaves the circulation, rather than the intact-labeled cells themselves64. These results suggeat that the labeling operation does not aignificanty damage the RBC. $\cdots$

A atudy was recently completed to derelop an in-riftro kit method for selectively labeling RBC ith 99m in whole blood ${ }^{54}$. Thts new method eliminates the main drawbacks of the previous mentioned methods, namely the need for separating plasma, centrifugations, muliple transfers, etc. The overall effectiveness of such a procedure was thought to be greaty dependent on maximizing the arailability of tin in the atamous form within the cella and at the aame time effectively reworing all the extracellular tin(II). Reduced techetium in most cases does not pass in or out of the cells and thus any premature extracellular reduction of pertechnetate results in considerably poor labeling yields. It was believed that the addition of an oxidizing agent which is not transported into the cells will render extracellular tin(II) ineffective by oxidizing it to tin(IV) (NaOCl was found most effective). The use of by pochlorite as an oxidant for tin (II) in plasma was suggested earlier by Narra and coworicers5. It was found54 that by pochlorite alone did not completely oxidize all the tin(II) and that labeling yields greater than $92 \pm 37$ could not be obtained. Use of a chelating agent such as EDTA (In combination with NaOCl) was found to increase the labeling ylelds to consistenty higher values ( $98 \pm 27$ ) elther by effectively sequestering the remaining tin(II) and thus making it more accessible to the hy pochlorite, or by other possible mechanisms. Representative data are sumarized in Tables 6 and 7.

Comparable labeling efficiencies at the tracer level are achieved regardless of whether $g$ lucoheptonate (GH), citrate (CIt), or other suitable ligands are used as complexing agents for tin in the $k i t$. However, tin uptake into the RBC is higher with GH and $C 1 t$ and the use of these 1 igands may thus be more adrantageous especially in situations where excessive amounts of ${ }^{99} \mathrm{TC}$ are present in $99{ }^{\mathrm{m}} \mathrm{TC}$ solutions (e.g., when using instant techetiun, or the first generator milking following an overly long ingrowth period). The effect of carrier on labeling y felds is shown in Table 8 .

The data in Tables 6-8 were obtained using $k 1 t 3$ containing $15 \mathrm{~kg}$ stannous tin. Similar resulta are obtained using a later version of tin citrate kits that contains $50 \mathrm{pg}$ tin.

The new kit for labeling RBC in whole blood consists of the following:

One Vacutainer reagent tube $100 \times 15 / 16 \mathrm{~mm}-10-\mathrm{ml}$ capact ty, or a $10 \mathrm{ml}$ multi-injection bottle, evacuated to draw up to $6 \mathrm{ml}$, and containing: $50.0 \mathrm{Hg} \mathrm{tin}, 3.67 \mathrm{mg}$ sodium citrate, $5.50 \mathrm{mg}$ dextrose, and $1.40 \mathrm{mg}$ sodium chloride (maximu). 
The other reagents required during the labeling procedure (andw by pochlorite, EDTA) can be prepared or obtained as followa. These ary also becone arallable as part of the kit in the future.

Sodim bypochlorite. To prepare the sodiu by pochlorite (NaOCl) solution, dilute reagent grade Naocl (for exaple, J.T. Baker, reagent NaOCl, 5.25\%) with saline to give a 0.17 final concertration. Th1s solution should be prepared fresh and aned the sane day.

EDTA. Directions for preparing and using the 4.47 EDTA solution are Identical to those provided In an earlier section (vide supra).

The labeling protocol is as follows:

Use aseptic techniques throughout the procedure.

i. Draw 1 al of patient blood ( 0.5 to $6 \mathrm{al}$ ary be used) into a heparinized oyringe and add to the $k 1 t$ tube.

2. Mix Imediately to dissolve the freeze-dried solida in the blood and incubate for five minutes at room temperature.

3. Add $0.6=1$ of 0.17 sodium by pochlorfte solution. Mix by gently Inverting the cube $3-4$ times.

4. Add I al of a 4.47 EDTA solution. Mix by gently inverting the tube 3-4 times.

5. Store the tobe in a lead shield and add the desired quantity of technetium-99m pertechnetate in a rolume of 0.5-3 m.

6. Incubate the techetiu-RBC mixture for fifteen ainutes at roow temperature with occasional gentle mixigg.

7. The above procedure $y$ Ields an excellent agent for blood pool imaging and red cell wass studies. Substitution of the following for step 6 produces an Ideal splenic agent: incubate the technetium-blood mixture 15 minutes at $49^{\circ} \mathrm{C}$ with gentle aixing. 
In sumary, the new $k 1 t$ method for selectire labeling of RBC in whole blood: (1) eliminates the need for separating plasma, and thus cell. remain in their native plasma environment, (\$1) requires no centrifugation and thus greatly reducea handling of RBC, (111) tolerates greater quantities of 99 TC contamination in 99 The eluntes, (17) involves one ressel operation and no-transfers, and thas 1 s more convenient to carry out 1n. practice, and ( $)$ profidea consistently high labeling efficlencies $(98 \pm 2 z$ ). Preliminary studies in dogs have demonstrated that the In-pivo survival of the label in blood is equal to or somewhat superior than that using other in-qitro labeling techiques.

A typical procedure which is routinely used at BNL for preparing tin clerate kits contafing 2 ug tin 18 described below.

Detalled Procedure for Preparing and Checking Red Blood Cell Rits

Reagents: (Sources given In parentheses; substitute sources may be used if reagent purity is comparable.)

Sterlle water for infection, U.S.P., pyrogen free

(Travenol Labs., Inc., Deerfleld, IL)

Anhydrous dextrose, U.S.P. (J.T. Baker Chemlcal Co.,

PhIllipaburg, $\mathrm{NJ}$ )

Trisodiun eltrate dihydrate, U.S.P. (Hallinckrodt Inc., Paris, RY)

Tin vire, $0.5 \mathrm{~mm}$ diameter (M5N-99.9997, Alfa/Ventron, Danvers, MA)

Concentratad bydrochloric acid, reagent grade

1 s sodim hydroxide, reagent grade

Appara+us:

N1trogen glove box

Laminar flow hood

Hot plate-stirrer

Freeze drier

Magnetic stirrer

Balance
Repipet dispenser

Autcclave

Hot-alx oren

Sample aluminum block

0.22 um sterile M1IIIpore filters

Glassware:

500-10 ml sterile Vacutainer tubes $w /$ atoppera

1-1000 ml Er lenmey er flask

Large (4") watch glass

2-disposable pipettes w/bulbs

1-10 ml volumetric

1-200 ml volumetric
1-250 al vol wetric

1-10.0 ml pipette (volumetrir)

1-2.0 ml pipette (volumetrit)

$1-4.0 \mathrm{ml}$ plpette (volumetric)

1-10 $\mathrm{ml}$ beaker

1-100 ml beaker

20-30 ml sterl:a multi-injection bottles 
1. Prepare glassware and laminer flow hood according to standard USP procedures.

2. Thoroughly clean the nitrogen glore box by wiping imer walls and equipment with wet Riwipes.

3. Boll 700 al aterile water for infection in aterile 1 ilter Erlenmeyer flask covered with a sterile watch glass. Allow to cool

. overnight, covered with a watch glass and stored Inside the laminar flow hood.

4. Wash 1 piece of tin wire $4.08 \mathrm{~cm}$ in length $(0.5 \mathrm{~m}$ dian.) weighing about $52.6 \mathrm{mg}$ in beaker with acetone, dry vith nitrogen, and transfer to a $10 \mathrm{ml}$ voluetric inside nitrogen glove box. Cover the tin wire with $2 \mathrm{ml}$ concentrated HCl. Heat gently to dissolve. After cooling, dilute to rolue with bolled aterile water. This is solution " $A$ ", which contains $\sim 5.3 \mathrm{mg} / \mathrm{ml}$ tin in $2.4 \mathrm{~N} \mathrm{HCl}$.

5. Prepare the citrate solution by dissolving 36.70 \& trisodiun citrate dibydrate in $80 \mathrm{ml}$ bolled aterile water in a $100 \mathrm{ml}$ beaker.

6. Add dropwise, under stiring, $4.0 \mathrm{ml}$ solution " $\mathrm{A}$ " to the $100 \mathrm{ml}$ beaker containfing the above citrate solution while keepizis the pH between 6 and 7.5 by ajding $1 \mathrm{H}$ HaOH dropwise as necessary. Final pH should be 7-7.5. Quantitatively transfer this solution to a 200 ml volumetric using water and dilute to rolume with water. This is

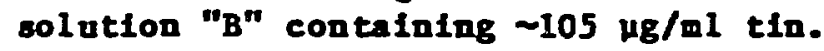

7. Aseptically, transier $13 \mathrm{ml}$ aliquots of solution "B" into sterile $30 \mathrm{ml}$ multi-injection bottles and quick-freeze. Store the rials in a freeser, until ready to use.

8. Allow one $30 \mathrm{ml}$ bottle containing $13 \mathrm{ml}$ frozen stannous cltrate to come to room temperature fust before use. Transfer $10 \mathrm{ml}$ of this solution into a $250 \mathrm{ml}$ volumetric containing $2.75 \mathrm{~g}$ anhydrous dextrose dissolved in sterile water. Ralse the volue to maxk with sterile-water. - This-is solutions "C" containing-4 $\mu g / m I$ Sn(II). The above operations are carried out inside the nitrogen-filled glove box.

9. Remove solution "C" from the glove box after filtration through a sterile 0.22 pm Millipore filter into the sterile dispensing apparatus.

10. Dispense $0.5 \mathrm{ml}$ filtered solution " $\mathrm{C}$ " Into sterile Vacutainer tubes and Imediately freese by transferring to the aluinum block surrounded by dr; ice. The dispensing assembly $1 \mathrm{~s} \mathrm{kept}$ under an a tmosphere of sterile, filtered $\mathrm{N}_{2}$. This operation 1 s carried out inside the laminar flow hood with the ur light on.

11. Stopper the tubes making sure there $1 \mathrm{~s}$ a big erough opening to allow for proper vapor escape:

12. Place the Inside frees drier whose shelf bas been precooled to $<-40$ cC. sition to punp $\sim 24$ hr without applying shelf heat and then $24 \mathrm{hr}$ with shelf heated to 110 ar. Fill the drier chamber with nitrogen to $16^{\mathrm{m}} \mathrm{Hg}$, and remotely stopper the tubes. Renore from the freere-drier.

13. Immediately Irradiate the stoppered tubes with a total of $2.5 \times 10^{6}$ rads using a ${ }^{60} \mathrm{Co}$ source.

14. Send out random samples to independent laboratories for sterility and py rogen testing.

15. Check, red cell labeling jields with representative sample tubes; in duplicate, using both no-carrier-added as vell as carrier-added 99mTc solutions. 
Typical images of the heart obtained following the injection of In-vitro kit labeled RBC are ahown in Figure 7. A representative dynam?: osto using gated data acquialtion is shown in Figures 8 and 9.

(b) In-rivo method. Labeling of red cells.with 990Te can also be carried out in $\nabla 170$. The nethod is based on the observation that prior administration of stannous compounds causes alterations in the aubsequent in-vivo distribution of pertechnetate56. Pertechnetate alone does not bind strongly with red cells, but in vivo because of the prior introduction of $t i n$ (II) in the red cell compartment, the administered pertechnetate after finding entry into the cells gets reduced and firmly bound. Pavel and co-workers 53 introduced this method for RBC labeling in vivo and found stannous pyrophosphate to be most effective. Labeling efficiency (fraction of the total administered pertechetate incorporated into the red cella), however, is variable, usually ranging anywhere between 60 and $90 \%$. The exact role of stannous lon in the labeling process has not been completely elucidated. It has been proposed thet fin(II) selectively activates the redox mechanisms in the chorold plexus and red cells thus causing in-situ reduction of the pertechnetate and 1 ts retention primarily at these two sites. Compared to the in-vitro wethod which routinely prorides quantitative labeling of the cells (a necessary requirement for mum applications), the in-vivo method results in generally poor and frequently irreproducible labeling effictencies. Its usefulness, however, camot be disputed, especfally because of the convenience. The process requires only two injections and no outside handling of blood is involved. When higher labeling efficiencies are required, and for splenic studies, in-vitro labeling is the wethod of cholce.

Varlous parameters such as the optimum quantity of the tin(II) preparation to be injected and the appropriate time delay between tin injection and the pertechnetate administration, etc. have been studied by various investigators57-59. Administration of 10 to $20 \mathrm{\mu g}$ of stannous lon per kilogram of body weight is thought to be adequate for optimal labeling. A cromercial stannous pyrophosphate $k$ it containing 2 ag stannous ion is reconstituted with saline and a suitable aliquot (depending upon the patient' weight) is injected into the patient. After $30 \mathrm{~min}$, the desired quantity of $99 \mathrm{~m}_{\mathrm{TcO}_{4}}^{-}$(usually 10 to $30 \mathrm{mCI}$ ) is injected intravenousiy. The red cells get labeled almost immediately and the technetium activity incorporated lato the cells has a clearance half-time of about 30 hr or more 60 . The stannous ion taken up by the cells appears to have a quite slow clearance. Thus, it appears that following perteclmetate injection up to several days after the patient has had a 99 me-Sn-py rophosphate bone study performed, significant in vivo cell labeling with $99 \mathrm{~m}$ Te can occur.

The long-term retention of tin following in-viro RBC labeling was the subject of a recent study60. The data fron this study are sumarized in rables 9-10. It was found that: (1) There is a significant retention of tin in the $R B C$, even after a period of two months following a angle Sn-PYP injection. (1i) Early blood samples (following tin administration) give high labeling ylelds (in vitro) with 99wc; sowe labeling is achiered eren with twomonth samples. (11i) The kinetics of the 99 Tre labeling of RBC (in ritro) alow down considerably 
with the later samples. This way be due to the slow lose of Sn(II) fron the cells or Its oxidation to Sn(IV). Nornal loss of RBC (and thus of tin) from the circulation as also be an important contributiag factor. (1V) Significant in-Fivo labeling of RBC reaults when $99 \mathrm{TcO}_{4}^{-1}$ is injected up to 42 day a after a ingle Sn-PIP adninistration. ( $\nabla$ ) Blood samples obtained 60 min after the injeciton of 99 TCO $_{4}^{-}$showed that the activity in blood ( $z$ injected dose) was high for early perfods after the Sn-PYP Injection ( $30 \mathrm{~min}, 98.5)$ and dropped slowly with tine (7 d, 41 ; $21 \mathrm{~d}, 27.5 ; 42 \mathrm{~d}, 25.4)$. The ratio of RBC to plase actirity also decreased with tine (30 min, 19; $7 \mathrm{~d}, 1.75 ; 21 \mathrm{~d}, 0.39 ; 42 \mathrm{~d}, 0.20)$.

(c) Combined In-vivo/in-vitro ("In-rivitro") Hethods. Some Investigators claim to overcome the variable tagging achieved with the in-rivo proces sre with the adaptation of the "1n-viritro" nethod61-63. The method basically is an In-viro "timing" procedure followed by presentation of 99 mc-pertechetate activits to a smaller number of RBC In ritro and reinjecting the labeled RBC in plasma into the patient. A typical procedure 61 is presented below in view of 1 ts use at various centers.

Modified in viro labeling of red blocd cells

1. Pretreatment with 0.5-1 mg stannous 10n as stannous py rophosphate (I.V. Infection not through Indwelling catheter)

2. Place 19 gauge butterfly needle into antecubital vein.

3. Attach 4-way stopcock to butterfly; place $10 \mathrm{ml}$ gyringe containing $4 \mathrm{ml}$ heparin $(10 \mathrm{mita} / \mathrm{al})$ and $4 \mathrm{ml} 0.97 \mathrm{kaCl}$ on free port of stopeock.

4. Flush butterfly and tubing ulth heparin saline solution.

5. $20 \mathrm{~min}$ after injection of atamous reagent, attach a shielded $5 \mathrm{ml}$ oy ringe containing, $20 \mathrm{mCl}$ of $99 \mathrm{mTC}$ pertechetate to free port of stopcock.

6. Wlthdraw 3 or of blood into 99me gringe.

7. Flush butterfly and inhing with heparin saline solution.

8. Invert the $99 \mathrm{~m}$ TC-RBC oy ringe every $1 \mathrm{~min}$ for ten minutes; then inject labeled red cella ria the indwelling butterfly needle.

(d) Mechanistic studies. The mechanism involved in the $99 \mathrm{~m}_{\mathrm{Te}-\mathrm{RBC}}$ labeilng process is not completely understcod. Howerer, some evidence has been accumulated $64-67$ to support the following concinsions: (1) stannous ion corplexed with citrate or other sultable agents diffuses Into the cell and becomes bound to a cellular component, (2) pertechetate lon diffuses freely in and ont of the cell, (3) pertechetate, once inside the cell and if tin(II) is already present there, gets reduced and bound mainly to the globin part of hemoglobin, (4) the binding of techaetiun with globin is predominanty to the B-chain, (5) reduced forms of technetio cannot be transported across the cell aembrane, and (6) am tin(II) remaining outalde of the cells prematurely reduces the pertechetate thus forbidding the entry of technetiun into the cells and thereby causing low labeling Jields. It thus becomes necessary to remove excess tin before adding pertechetate. Data on the uptake and distribution of 99 me and tin (117 $\mathrm{ma}$ or ${ }^{113} \mathrm{Sa}$ was used) In blood and within the red cell components 54 are described in Tables 11-14. 
Al terationa in the binding of teclmetiu-99: by red cell s have been reported as a result of varlous patient nedications68,69 as well as from diseases or medications asociated with RBC antibody formetion70. The exact nechaniama responsible for these effects are not known.

(e) Comparison of 99mTc-RBC with 99wc-HSA. The activity concentration of 99 Tre in blood is significantly higher with 99 me-RBC as compared to 99 mc-HSA (human serum albunin) for sereral hours after injecticn. For a number of reasons 71 , 99 m Tc-HSA preparations with farorable blood clearance characteristics are not easily achierable. For blood pool Imaging, especially of the cardiac chambers, labeled RBC have thus proven to be superior to labeled HSA in several recent studies 72,73 Some of the representatire data are shown in Figures 6-8.

(f) Splenic studies. Heat-damaged technetium-99m RBC (99mTc-HDRBC) find application in the imaging of apleen which is useful in a nubr of clinical situations including traums, investigation of left upper quadrant masses or pain, evaluation of spleen size, splenic infarcts and space occupying disease, and accessory splecus 74,75 . Specificity higher. than 99 me-sulfur colloid 18 obtained by using $99 \mathrm{~m}^{\mathrm{m}}$ Tc-HDRBC. Heating at $49.5^{\circ} \mathrm{C}$ is a very reliable techique for inducing splenic sequestration

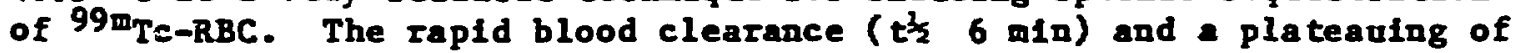
the activity in the spleen by 30 ainutes wake it possible to accomplish imaging soon after the radionuclide administration75. High splenic uptake ( $70 \%$ ) allows the administration of small quantities of the radiotracer ( $1 \mathrm{mCl}$ is adequate for rapid imaging in multiple views) thus reducing the patient radiation dose considerably Representative spleen images are shown in Figure 12, obtained using $99 \mathrm{mTc}-\mathrm{s}$ colloid and $99 \mathrm{~m}_{\text {TC-HDRBC }} 52$.

(g) Patient radiation dose. Arerage radiation doses to the whole body as well as to various other tisaues and organs from the administration of normal and heat damaged 99me-RBC are shown in Table 1575,76. The whole body dose 13 generally lower than that to many other organs which is due to the lower average blood content of whole body. 


\section{CONCLDSION}

Radiolabeling of red cella and their clinical and reaeach application in nuclear medicine imaging and other areas, has been a fleld of Intenne Interest during the last two decades. Significant adrances have been made so thet at the present time auficiently stable labels are arailable for various applications. Techetium-99n labeled RBC have revolutionized the field of nuclear cardiology and it is now possible to evaluate various heart parameters externally without significant radiation doae or trauma to the patient.

The ideal radioisotopic label for the determination of red cell life span in normal and hemoly tic states is yet to be developed. The tracers avallable so far especially 5 lCI-RBC have provided raluable Information, but occasionally given pisleading resulta as well. Caution has to be exercised when interpreting the results.

For various clinical procedures, the choice of label varies. Red cells labeled with long ( $-90 \mathrm{~d})$ as well as intermediate $(2-3 \mathrm{~d})$ half-1ife nuclides with sufficient in-vivo stability are highly desirable. Future work will perhaps fulfill this need now that we bare acquired a strong base of useful knowledge on radiolabeled red sells. Lpproaches such as using labeled antibodies to red cell antigens or receptors, or enzynes in the cell may provide encouraging results in terms of labeling RBC with the least damage.

\section{ACKNOWLEDGMENTS}

The secretarial assistance of Mrs. R. Balley during varlous stages of the preparation of this manuscript is gratefully acknowledged. This work was supported by the United States Department of Energy under Contract tDE-ACO2-76CHOOO16. 
REFERENCES

1. The Red Blood Cell, C. Bishop and D. M. Surgenor, eds., Acadenle Preas, Nex' 'Tork (1964).

2. R. Whttam, Transport and diffusion in red blood cells, Bdward Arnoli, London (1964).

3. H. Pollycove and $H$. Tono, Studies of the erythron, Semin. Hucl. Hed. $5: 11-61$ (1975).

4. N. I. Berlin, Determination of red blood cell life span, J. Amer. yed. As8oc. 188:375 (1964).

5. M. S. Wheby and H. H. Crosby, The gastrolntestinal tract and Iron absorption, Blood 22:416 (1963)

6. I. Saylor and C.A. Finch, Determination of iron absorption using two Isotopes of Iron, Amer. J. Physiol. 172:372 (1953).

7. H. Pollycove, Iron metabolism and kinetics, Semin. Hemato1. 3:235 (1966).

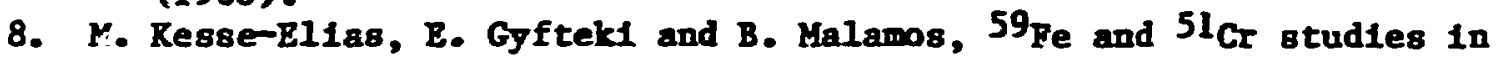
aplastic anemia and Eyelosclerosis, Acta Haemat. $39: 139$ (1968).

9. J. A. Cohen, M. G. P. Warringa, The fate of PJ2 labeled difsopropylfluorophosphate in the human body and its use as a labeling agent in the study of the turnover of blood plasma and red ce11s, J. C11n. Invest. 33:459 (1954).

10. I. E. Bratteby, L. Garby and B. Wadnan, Studies on erythrokinetics in infancy. XII. Survival in adult rectpienta of cord blood red cells labeled in vitro with d1-18opropyl fluorophosphate (DF32P), Acta Pediatr. Scand. 57:305 (1968).

11. S. J. Gray and R. Sterling, The tagging of red cells and plasma proteins with radioactive chromium, J. Clin. Invest. 29:1604 (1950).

12. F. G. Bbaugh, Jr., C. P. Rmerson, and J. F. Ross, The use of radjosctive-chromium-51-as-an-ergthroeyte-tagging agent for the deternination of red cell aurvival in vivo, J. Clin. Invest. 32: 1260 (1953).

13. R. C. Read, G.W. HIIson, and F.H. Gardner, The use of radioactive sodium chromate to evaluate the Iffe span of the red cell in health and in certain hematologic disorders, Amer. J. Med. Sc1. 228:40 (1954).

14. H. A. Pearson. The binding of 51 Cr to hemoglobin. I. In-vitro studies, Blood 22:218 (1963).

15. H. N. Hagner, Jr., I. M. Heiner, J. G. Mcafee, et al, 1-mercur1-2hydroxypropane (MHP): a new pharmaceutical for visualization of the 8pleen by radiolsotope scanning, Arch. Intern. Med. 113:696 (1964).

16. K. Mayer, A. Dwyer and J. S. Laughling Spleen scanning using ACD-damaged red celle tagged with 51 Cr, J. Nucl. Med. 11:455 (1970). 
17. P. H. Johnson, E. H. Hood, and S. L. Mooring, Splenie ecintillation scanning, Amer. J. Roentgen. 86:575 (1961).

18. F. Splnelli-Rese1, Scintillation scanning of the spleen with red cells labeled with chromium-51, In: Hedical Radiolsotope Scanning, Vol II, IARA, Viema, 1964, pp.355-369.

19. P. H. Johnson, J.C. Herion, and S.I. Hooring, Scintillation scanning of the normal human spleen utilizing sensitized radioactive

.. erythrocytes, Radiology 74:99 (1960).

20. M. I. Thakur, D. Dees, S. S. L. Harwig, et al, Labeling blood components with 8-hydroxyquinoline chelates: Simplified procedure and mechanism of labeling, J. Labeled Compds. Radiopharn. 13:177 (1977).

21. M. L. Thakur, Gallium-67 and Indium-111 radiopharmaceuticals, Int. J. Appl. Radiat. Isot. 28:183 (1977).

22. M. L. Thakur, M. J. Welch, J. H. Jolat, et al, Indium-11l labeled platelets: Studies on preparation and evaluations of in vitro and in vivo functions, Thromb. Res. 9:345 (1976).

23. M. L. Thakur, J. P. Lavender, R. N. Arnot, et al, Indim-111 labeled autologous leukocytes in man, J. Nucl. Med. 18:1014 (1977).

24. M. J. Welch, M. I. Thakur, R. E. Coleman, et aí, Gallium-68 labeled red cells and platelets. New agents for positron tonography, J. Nucl. Med. 18:558 (1977).

25. M. Murrell, $\because$. Scheffel, J. M. Whipple, et al, In-111-oxine as a red blood cell label, Prod. 2nd Intl. Congr. World Fed. Nucl. Heć. Biol. Washington, D.C., p.130 (1978).

26. G. G. Winzelberg, F. P. Castronovo, R. J. Callahan, et al, III In oxine labeled red cells for detection of simulated lower gastrolntestinal bleeding in an animal model, Radiology 135:455 (1980).

27. H. Sinn, P. Georg1, J. Clorius, et al, Die markierung von erythrozycen mit radioactiven indiumisotopen, Nuclear-Wedizin 13:180 (1974).

28. H. Sinn and D. J. S1Ivester, Simplified cell labeling with Indium-111 acetylacetone, Brit. J. Radiol. $52: 758$ (1979).

29. C. J. Mathias, H. A. Beaton, M. J. Welch, et al, Comparison of 111 In-oxtne and 111 In-acetylacetone for the labeling of cells: In-vivo and In-vitro blological testing, Int. J. Appl. Radiat. Isot. $32: 651$ (1981).

30. A. Ferrant, N. Dehasque, N. Leners, er. al, Scintigraphy with In-111-iabeled red cel18 in intermttent gastrointeatinal bleeding, J. Nucl. Hed. 21:844 (1980).

31. R. L, Beckman, G. I. Pittenger, D. P. Swenson, et al, Blood 1088 measured with Indium-111-labeled red blood cells in dogB, Radiology 148:243 (1983).

32. D. J. Hnatowlch, A nethod for the preparation and quality control of ${ }^{68} \mathrm{Ga}$ radiopharmaceuticals, J. Nucl. Med. 16:764 (1975).

33. D. D. Pant, J. J. Coupal, H. J. ShIh, et aI, A nev appronch to gallim-67 labeling of human ergthrocytes and platelet, J. Nucl. Med. $24:$ P123 (1983).

34. M. R. Dewanjee, S. A. Rao, J. A. Rosemark, et al, Indium-1II tropolone, a new tracer for platelet labeling, Radiology 145:149 (1982). 
35. H. I. Glass, A. Brant, J. C. Clark, et al, Heasurement of blood volume using red cella labeled with radioactive carbon monoxide, J. Nucl. Hed. $9: 571$ (1960).

36. G. Heresy and $G$. Hy $11 \mathrm{n}$, Application of $42_{\mathrm{K}}$ labeled red corpusclea in blood volume measurements, Acta Phy siol: Scand. 24:285 (1952).

37. S. A. Berson and $R$. S. Talow, The ase of $42 \mathrm{~K}$ or $3 Z_{\mathrm{P}-1 a b e l e d}$ ex throcy tes and $13 l_{I}$-tagged human serum albunin in simul taneous blood volume determinations, J. Clin. Invest. 31:572 (1952).

38. D. H. Ackery, J. Singi, and P. Wyeth, Enzyme-inhibitor mediated red cell labeling, Proc. $4 \mathrm{th}$ Intl. Symp. Radiopharm. Chem., Jullch, KFA, 1982, pp.253-255.

39. H. Jackson, Studied with exy throcy tes labeled with radioactive p-iodopheny lity droxy lamine, Heture 172:80 (1953).

40. D. Van Dyke, H. O. Anger and H. Pollycore, The effect of erg thropoeitic stimulation on marrow distribution in man, rabbit, and rat as shown by $\mathrm{Fe}^{59}$ and $\mathrm{Fe}^{52}$, Blood 24:356 (1964).

41. J. A. Penner, Selenomethionine incorporation into hemoglobin, Ciln. Res. $12: 228$ (1964).

42. S. C. Srirastara and P. Richards, Technetiur-labeled compounds, in: "Radiotracers for Hedical Applications," Vol. I, G. V. S. Ray udu, ed., CRC Press, Boca Raton, Florida, 1983, pp.107-185.

43. J. Fischer, R. Wolf and $A$. Leon, Technetium-99m as a label for exy throcy tes, J. Nucl. Hed. 8:229 (1967).

44. J. Haubold, H.W. Pabst and G. Hor, Scintigraphy of the placenta with 99xtc-labeled exy throcytes, in: Syuposium on Medical Radiolsotope Scintigraphy, Vol. 2, Viemaa, IAEA, 1969, pp.665-674.

45. M. B. Weinstein and U.M. Smoak, Technical difficulties in 99me-labeling of eiry throcy tes, J. Nucl. Med. 11:41 (1970).

46. R. Berger, B. Johanssen, Markierung von Ery throzy ten mit 99mTechnet1 um, Math-Naturwisa R/18:635 (1969).

47. J. P. Konel-and P.-Brunelle;-Le warquage-des hemetles par le techet1um 99m, Presse Hed. 78:73 (1970).

48. H. Eckelman, P. Richards, H. Hauser, et al, Technetium-labeled red blood cells, J. Hucl. Hed. 12:22 (1971).

49. R. D. Schwarte and M. Kruger, Improvement in labeling ery throcy tes with 99m-Tc-pertechnetate, J. Nucl. Med. 12:323 (1971).

50. W. C. Eckelman, R. C. Reba and S. N. Albert, A rapid simple improred method for the preparation of $\mathrm{Tc}^{99 \mathrm{~m}}$ red blood cells for the determination of Ied cell volume, Am. J. Roentgenol. Radiun Ther. Nuel. Hed. 118:861 (1973).

51. H. Le Atk1ns, W. C. Eckelmen, J. F. Klopper, et el, Vascular Imaging

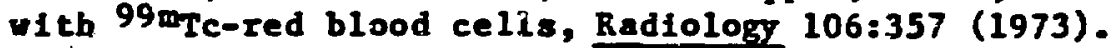

52. T. D. Snith and P. Blcinads, A simple kit for the preparation of 99me-1abeled red blood cells, J. Nucl. Hed. 17:126 (1976).

53. D. G. Pave1, A. H. Zimmer and V. K. Patterson, In vivo labeling of red blood cells with 99mes A new approach to blood pool visualization, J. Nuc1. Med. 18:305 (1977). 
54. S. C. Srivastara, J. B. Babich and P. Richards, A new kit nethod for the selective labeling of ery throcy tes in whole blood with techetium-99w, J. Nucl. Med. 24:P128 (1983).

55. B. K. Narra and B. I. Kucryadi, KIt for In ritro labeling of red blood cells with $99 \mathrm{mp}_{\mathrm{TC}}$, In: Applications of Ruclear and Radlochemistr, R. M. Lambrecht and H. Horcos, eds., Pergamon, New York, 1982, PP.153-161.

56. 'J. HeRae, R. M. Sugar, B. A. Shiples, et al, Alterations in tissue distribution of ${ }^{99} \mathrm{~m}$ Te pertechnetate in rats given atamous $t i n$, J. Nuc1. Hed. 15:151 (1974).

57. R. G. Hamilton and P. O. Alderaon, A comparative eraluation of techigues for rapid and efficient in-viro labeling of red cells with 99te, J. Nucl. Hed. 18:1010 (1977).

58. A. H. 21mer, D. G. PareI and S. M. Karesh, Technical parade ters of In-7ivo red blood cell labeling with technetiun-99m, Nucl. Med. $18: 241$ (1979).

59. H. H. B11IInghurst, D. Jette and D. Greenberg, Deternination of the optimal concentrations of stannous Fyrophosphete for in-vivo RBC labeling with 99m Tc, Int. J. Appl. Radiat. Isot. 31:499 (1980).

60. S. C. Srivastara, P. Richards, Y. Yonektra, et al, Long-term retention of tin following In-viro RBC labeling, J. Nucl. Med. 23:P91 (1982).

61. G. G. Winzelberg, K. A. MeKusick, I. W. Froelich, et al, Detection of gestrointestinal bleeding with 99 me-labeled red blood cells, Semin. Hucl. Hed. 12:139 (1979).

62. R. Armas, H. L. Thakur and A. Gottschalk, A simple nethod of spleen imaging with 99mTc-labeied ery throcy tes, Radiology 132:215 (1979).

63. B. J. Callahan, J. W. Froelich, K. A. McKusick et al, A modified method for the in viro labeling of red blood cells with Tc-99m: Conclae commication, J. Nucl. Hed. 23:315 (1982).

64. S. C. Srivastava, R. Straub and P. Richards, Onpublished data, 1983.

65. M. R. Dewanjee, Binding of Tc-990 to hemoglobin, J. Nuc1. Hed. 15:703 (1974).

66. M. K. Dewanjee and S. A. Rao, Hechanism of in Tiro red cell labeling with $99 \mathrm{~m}$ Tc-pertechetate and role of $\mathrm{Sn}^{2+}$ pup at RBC membrane on

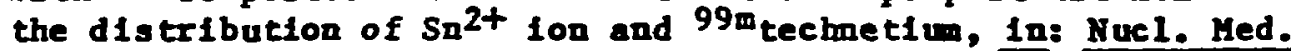

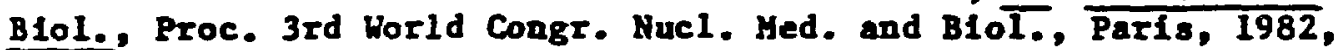
C. Raynaud, ed., Pergamon, Parla, 1982, pp. 1894-1897.

67. M. M. Rehani and S. K. Sharma, Site of TC-99m binding to the red blood cell, J. Nucl. Hed. $21: 676$ (1980).

68. I. R. Cherru, J. J. Castronuovo, S. S. Huq, et al, Alterations in red cell tagging with sulfonamides, J. Hucl. Med. 22:P70 (1981).

69. H. B. Lee, J. P. Hexler, S. C. Scharf, et al, Pharmacologic alterations in Tc-99m binding by red blood cellat Conclse comminication, J. Nucl. Hed. 24:397 (1983).

70. G. P. Leitl, H. H. Drew, H. E. Relly, et al, Interference with Tc-99a labeling of red blood celle (RBCs) by RBC antibodies, J. Nucl. Med. 21: P44 (1980). 
S. C. Srivastava

71. G. Meinken, S. C. Srivastava, T. D. Smith, et al, Is there a "good" 99 me-albumin?, J. Nucl. Med. 17:537 (1976).

72. J. A. Dahlstrom, S. Carlsson, B. LIlja, et al, Cardiac blood pool Imaging - A clinical comparison between RBC labeled with 99 me in vivo and in vitro and 99mTc-HSA, Nuclear-Medizin 18:271 (1979).

73. H. L. Atkins, J. F. Rlopper, A. N. Ansari, et al, A comparison of 99me labeled HSA and In $\nabla$ itro labeled RBC for blood pool studies, - Clin. Nucl. Med. 5:166 (1980).

74. H. L. AtkIns, H. C. Eckelman, H. Hauser, et al, Splenic sequestration

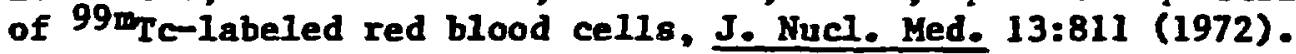

75. H. L. Atkins, A. G. Goldwan, R. F. Falichild, et al, Splenic sequestration of 99 melabeled heat treated RBC, Radiology 136:501 (1980).

76. H. Malamud, Dosimetry of $99 \mathrm{~m}$ Tclabeled blrod pool scanning agents, C11n. Nucl. Med. 3:420 (1978). 


\section{Table 1}

Red Cell Label:

\begin{tabular}{|c|c|c|c|c|c|}
\hline Nuclide & Compound used & In vivo & In vitro & Randon & Cohort \\
\hline${ }^{55} \mathrm{Fe},{ }^{59} \mathrm{Fe}$ & $\begin{array}{l}\text { Ferrle chloride } \\
\text { Ferrous citrate }\end{array}$ & $x$ & & & $x$ \\
\hline $15_{\mathrm{N}},{ }^{3} \mathrm{H},{ }^{14} \mathrm{C}$ & Glycine & $x$ & & $x$ & $\mathbf{x}$ \\
\hline $15_{\mathrm{N}},{ }^{3} \mathrm{H},{ }^{14} \mathrm{C}$ & DPP & $x$ & & $\mathbf{x}$ & $\mathbf{x}$ \\
\hline $32 \mathrm{P}$ & DFP & $x$ & & $x$ & $x$ \\
\hline${ }^{51} \mathrm{Cr}$ & Chromate & $\mathbf{x}$ & $x$ & $x$ & \\
\hline 111 In & $\begin{array}{l}\text { Oxine, } \\
\text { Acetylacetone, } \\
\text { Tropolone }\end{array}$ & & $x$ & $x$ & \\
\hline${ }^{68} \mathrm{Ga}$ & - & & $\cdot x$ & $=$ & \\
\hline $99 \mathrm{~m}_{\mathrm{TC}}$ & Pertechnetate & $x$ & $\mathbf{x}$ & $x$ & \\
\hline
\end{tabular}

Table 2

D1agnostic Applications of Radiolabeled Red Celis

Normal

1. Nuclear cardiology

2. Blood pool lmaging

3. Detection of vascular malformations

4. Detection of G.I. bleeding

5. Detection of hemanglomas

6. Red cell mass determination

7. Red cell life-span measurement

Beat-Damaged

1. Spleen Imaging

2. Accessory opleen localization

3. Detection of G.I. bleeding 
Table 3

Effect of EDTA Addition 78 . Saline Addition on the Labeling Bfficlency and stability of $99 \mathrm{~m}_{\mathrm{TC}}-\mathrm{RBC}$ Daing the BNL Rit

Saline Addition

EDTA Add1tion

Labeling gield,

$97.1 \pm 0.9$

$98.7 \pm 0.6$

percent

99m washout 2

$30 \mathrm{~min}$

$$
2.5 \pm 0.3
$$

$1.6 \pm 0.2$

$24 \mathrm{hr}$

$10.7 \pm 2.4$

$5.6 \pm 1.4$

IAfter Incubating i ml blood with the kit for 5 minutes, and prior to centrifugation, either $6 \mathrm{ml}$ saline or $1 \mathrm{ml}$ $4.47 \mathrm{Na}_{2} \mathrm{EDT}$ a were added, $\mathrm{n}=5$.

2washed, labeled cells were incubated wth saline at room temperature, and perlodic allquots removed to determine the 1088 of 99mT from the cells. 
Table 4

Technet1um-99a/Chromium-51 Red Cell Mass Ratios

\begin{tabular}{|c|c|c|c|c|}
\hline $\begin{array}{c}\text { Patient } \\
\text { No. }\end{array}$ & $\begin{array}{l}\text { Sampling } \\
15\end{array}$ & $\begin{array}{l}\text { time after } \\
30\end{array}$ & $\underset{60}{\text { injection }}$ & $\begin{array}{l}(n+n) \\
120\end{array}$ \\
\hline 1 & 1.05 & 1.01 & 1.05 & 1.03 \\
\hline 2 & 0.96 & 0.93 & 1.01 & 1.04 \\
\hline 3 & 1.00 & 1.01 & 1.06 & 1.08 \\
\hline 4 & 1.01 & 0.97 & 1.03 & 1.05 \\
\hline $\begin{array}{c}\text { mean } \\
\text { s.d. }\end{array}$ & $\begin{array}{l}1.01 \\
0.03\end{array}$ & $\begin{array}{l}0.98 \\
\pm \\
0.03\end{array}$ & $\begin{array}{l}1.04 \\
0.02\end{array}$ & $\begin{array}{l}1.05 \\
\pm \pm \\
0.03\end{array}$ \\
\hline
\end{tabular}

Table 5

99 me/51 $^{5}$ r Ratios in Blood In Dog Using Double Labeled RBC

\begin{tabular}{cc}
\hline $\begin{array}{c}\text { Time (hr) } \\
\text { after injection }\end{array}$ & Ratio \\
\hline 0.25 & 1.00 \\
0.5 & 0.99 \\
2 & 0.96 \\
4 & 0.89 \\
21.5 & 0.59 \\
25.5 & 0.54 \\
\hline
\end{tabular}


Table 6

Effeet of Sodiun Hypochlorite (NaOCl), EDTA, and Plasme on the Te-99m Labeling of Red Blood Cellt Using BLL Tin Citrate (15 pig $\mathrm{Sn}^{2+}$ ) Rits

\begin{tabular}{|c|c|c|c|}
\hline \multirow[b]{2}{*}{ Sample and treatment } & \multicolumn{3}{|c|}{ Tc-99m Activity, $Z$} \\
\hline & $\mathbf{R B C}$ & Superna tant & $\begin{array}{c}\text { 2, } 2 \text { ml saline } \\
\text { washes }\end{array}$ \\
\hline \multicolumn{4}{|l|}{ Whole blood } \\
\hline No $\mathrm{NaOCl}$ & $1.8 \pm 0.3$ & $87.1 \pm 1.6$ & $11.3 \pm 0.5$ \\
\hline$\underset{\text { added }}{\mathrm{NaOCl}}(0.6 \mathrm{ml}, 0.1 \mathrm{z})$ & $93.3 \pm 0.4$ & $5.2 \pm 0.4$ & $1.5 \pm 0.2$ \\
\hline $\begin{array}{l}\text { Naocl (as above) + EDTA } \\
\text { ( } 1 \mathrm{ml}, 4.47 \text { ) added }\end{array}$ & $98.0 \pm 1.2$ & $1.5 \pm 0.3$ & $0.5 \pm 0.1$ \\
\hline \multicolumn{4}{|l|}{ RBC (Plasma remored } \\
\hline \multicolumn{4}{|l|}{ after thnning) } \\
\hline Naocl (as above) added & $99.6 \pm 0.3$ & $0.4 \pm 0.3$ & $-\infty$ \\
\hline
\end{tabular}

Table 7

Effect of Adding EDTh after NaOCl and Prior to Pertechnetate Addition on the Tc-99m Labeling of Red Blood Cells

\begin{tabular}{|c|c|c|}
\hline \multirow[b]{2}{*}{ Condtitions } & \multicolumn{2}{|c|}{ Tc-99m Activity, Z } \\
\hline & $\mathbf{R B C}$ & $\begin{array}{c}\text { Supernatant } \\
\text { (including } 2,2 \mathrm{ml} \\
\text { saline washes) }\end{array}$ \\
\hline
\end{tabular}

Tin citrate kits, $n=10$

(15 $\mu \mathrm{g} \mathrm{Sn}{ }^{2+}$ )

No EDTA.

$\begin{array}{ll}93.3 \pm 0.4 & 6.7 \pm 0.4 \\ 97.7 \pm 1.2 & 2.3 \pm 1.2 \\ 98.0 \pm 1.2 & 2.0 \pm 1.2\end{array}$

$1.0 \mathrm{EI}$ EDTA, FH 4.6

1.0 mI EDTA, $\mathrm{pH} 7.2$

$98.0 \pm 1.2$

$2.0 \pm 1.2$

Tin glucoheptonate $k 1 t s$, I -15

(15 $28 \mathrm{Sn}^{2+}$ )

No EDTA

$95.2 \pm 1.0$

$4.8 \pm 1.0$

1.0 al EDTA, pH 4.6

$98.0 \pm 0.2$

$2.0 \pm 0.2$

$1.0 \mathrm{mLDTh}, \mathrm{PH} 7.2$

$97.6 \pm 1.0$

$2.4 \pm 1.0$ 
S. C. Srivastava

Table 8

Effect of Carrier ${ }^{99}$ Te on RBC Labeling Yields (3 al whole blood, n-4)

99 Te added, 799ure Aetivity

equivalent to $x$

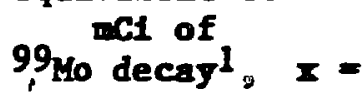

IIn glucoheptonate kit:

$\left(15 \mu \mathrm{g} \mathrm{Sn}^{2+}\right)$

$0 \quad 500 \quad 600$

In citrate kits

(15 $18 \mathrm{Sn}^{2+}$ )

ino decay's 2

RBC

$\begin{array}{cccccc}97.3 & 97.3 & 72.7 & 97.9 & 96.8 & 90.8 \\ \pm & \pm & \pm & \pm & \pm & \pm \\ 2.4 & 0.8 & 10.8 & 1.8 & 2.1 & 7.3\end{array}$

Supernatant

$\begin{array}{ll}2.7 & 2.7 \\ \pm & \pm\end{array}$

2. 7

27.3

2.1

3.2

9.2

2.4

0.8

$\pm$

$\pm$

$\pm$

$\pm$

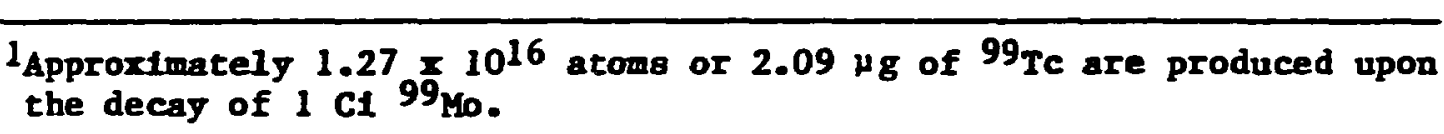

Table 9

In-VItro RBC Labeling with 99me of Blood Samples Obtalned at Various Intervals Following Sn-PYP Injection in Normal Human Volunteers ( $\mathbf{n}=4)$

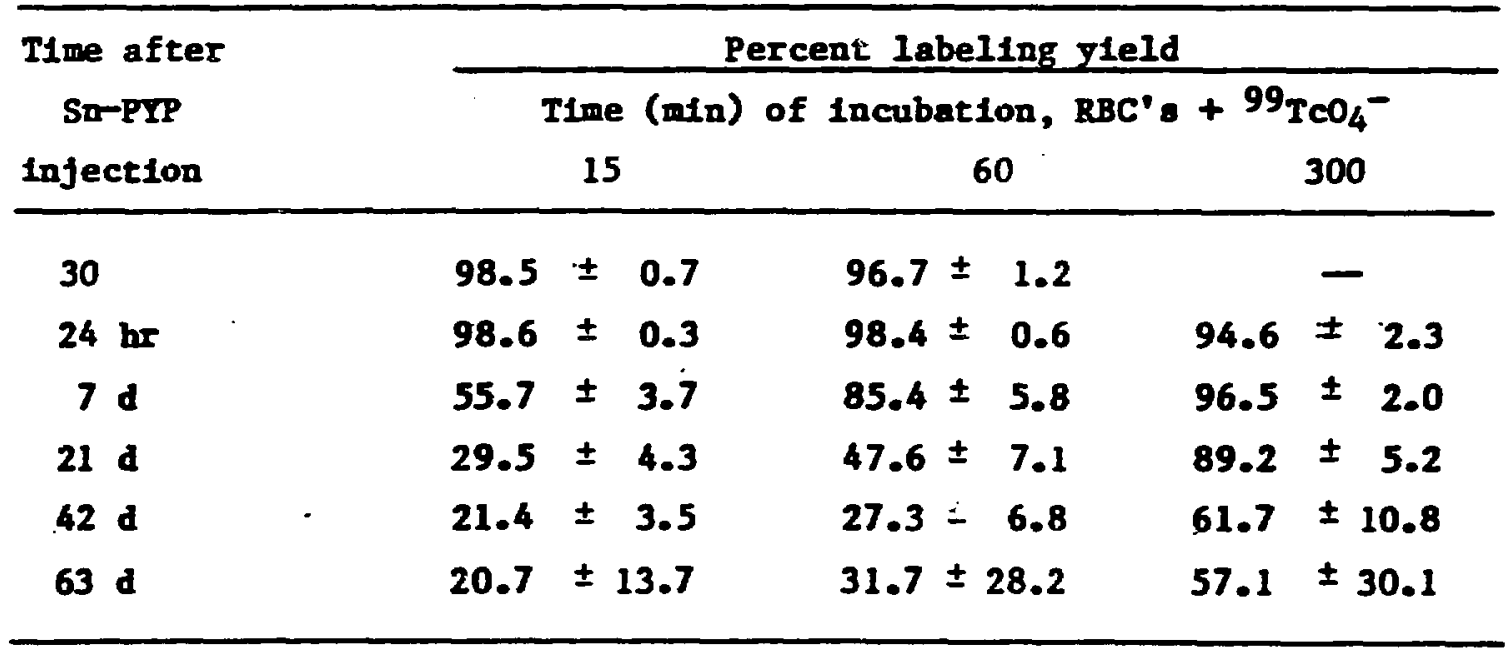


Table 10

In-Vivo RBC Labeling with 99mpe In Normal Human Voluteera at Various Intervala Following a Single Sn-PYP Injection (n=3)

\begin{tabular}{|c|c|c|c|c|c|c|c|c|}
\hline \multirow{2}{*}{$\begin{array}{c}\begin{array}{c}\text { Time of } \\
99 \mathrm{meO}_{4}^{-} \\
\text {1nfection }\end{array} \\
\begin{array}{c}\text { (post Sn-PIP) } \\
30 \mathrm{~min}\end{array}\end{array}$} & \multirow{2}{*}{ 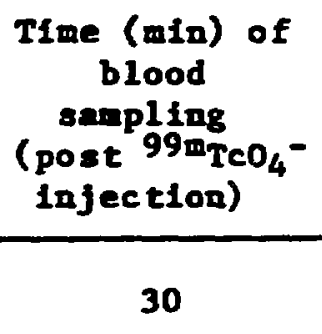 } & \multirow{2}{*}{$\begin{array}{c}\begin{array}{c}99 \text { we in Blood } \\
(z \text { of total lnjeeted, } \\
\text { normalized })\end{array} \\
100.0\end{array}$} & \multicolumn{6}{|c|}{$\begin{array}{l}\text { Percent of 99mTc (total) } \\
\text { Plasma (plus } \\
2 \text { ml salin } \\
\text { RBC }\end{array}$} \\
\hline & & & 94.5 & \pm & 2.5 & 5.5 & \pm & \\
\hline & 1440 & $71.6 \pm 1.5$ & 92.9 & \pm & 1.0 & 7.1 & \pm & \\
\hline \multirow[t]{2}{*}{$7 d$} & 60 & $41.2 \pm 9.5$ & 63.6 & \pm & 3.3 & 36.4 & \pm & \\
\hline & 300 & 39.4 & 90.3 & & & 9.7 & & \\
\hline \multirow[t]{2}{*}{$21 d$} & 60 & $27.5 \pm 2.8$ & 27.9 & \pm & 3.6 & 72.1 & \pm & \\
\hline & 300 & $20.2 \pm 1.2$ & 43.8 & \pm & 2.9 & 56.2 & \pm & \\
\hline \multirow[t]{2}{*}{$42 d$} & 60 & $25.4 \pm 2.7$ & 16.5 & \pm & 0.8 & 83.5 & \pm & 0.8 \\
\hline & 300 & $16.6 \pm 3.3$ & 16.7 & \pm & 2.5 & 83.3 & \pm & 2.5 \\
\hline
\end{tabular}


Table 11

Effect of Blood Volume and Amount of Tin(II)

In RIt on RBC TIn Jptrice (n-5)

\begin{tabular}{|c|c|c|}
\hline \multirow{2}{*}{$\begin{array}{r}\text { Blood } \\
\text { used } \\
(\mathrm{al})\end{array}$} & \multicolumn{2}{|c|}{ 7 Ifn uptake into RBC } \\
\hline & $15 \mathrm{\mu g} \mathrm{kit}$ & 50 $\mathrm{ug} \mathrm{kit}$ \\
\hline 1 & $12.3 \pm 1.2$ & $9.5 \pm 0.1$ \\
\hline 2 & $19.3 \pm 1.2$ & $12.5 \pm 0.2$ \\
\hline 3 & $25.7 \pm 0.3$ & $15.9 \pm 1.1$ \\
\hline 4 & $28.9 \pm 3.7$ & $20.9 \pm 1.1$ \\
\hline \multicolumn{3}{|c|}{ 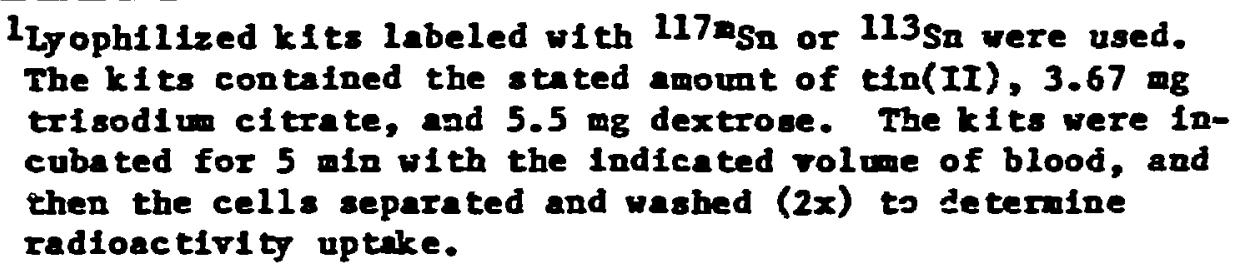 } \\
\hline
\end{tabular}

Table 12

Percent Distribution of Tin in Blood Components

Following In-V1tro Labeling (Blood Volve $3 \mathrm{al}$; n=10)

\begin{tabular}{|c|c|c|c|}
\hline \multirow{2}{*}{$\begin{array}{l}\text { Tin } \\
\text { content } \\
\text { of } k i t \text {, } \\
\mu g\end{array}$} & \multicolumn{2}{|c|}{ Red cell bound } & \multirow{2}{*}{$\begin{array}{c}\text { Plasma } \\
\text { (Including wash) }\end{array}$} \\
\hline & Membrane & Non-nembrane & \\
\hline 2 & $4.0 \pm 2.0$ & $17.5 \pm 9.7$ & $77.1 \pm 12.1$ \\
\hline 15 & $5.7 \pm 2.9$ & $18.3 \pm 5.1$ & $77.1 \pm .4 .2$ \\
\hline
\end{tabular}


Table 13

Percent Distribution of 99witc in Blood Components

Following In-Vitro Labeling $(n=10)$

\begin{tabular}{lllll}
\hline $\begin{array}{c}\text { Tin } \\
\text { content } \\
\text { of } \mathrm{k} 1 \mathrm{t}, \\
\mu \mathrm{g}\end{array}$ & \multicolumn{2}{c}{ Red cell bound } & & \\
\cline { 2 - 5 } & Membrane & Non-membrane & Plasma & Wash \\
\hline 2 & $1.7 \pm 0.3$ & $94.8 \pm 2.0$ & $2.7 \pm 1.7$ & $0.6 \pm 0.3$ \\
15 & $1.3 \pm 0.2$ & $93.3 \pm 3.2$ & $6.1 \pm 3.0$ & $0.7 \pm 0.1$ \\
\hline
\end{tabular}

Table 14

Percent Distribution of $99{ }^{\mathrm{m}} \mathrm{TC}$ and Tin in Hemoglobin ( $\left.n=10\right)$

\begin{tabular}{|c|c|c|}
\hline Fraction & $\begin{array}{l}\text { Technetiun } \\
\left(99 \mathrm{mTC}_{\mathrm{TC}}\right)\end{array}$ & $\left(113_{\mathrm{Sn}}^{\operatorname{Tin}}\right.$ or $\left.117_{\mathrm{mSn}}\right)$ \\
\hline Heme & $18.3 \pm 9.8$ & $90.1 \pm 4.5^{1}$ \\
\hline Globin & $80.5 \pm 10.1$ & $12.9 \pm 4.2$ \\
\hline
\end{tabular}


Tabie 15

Radiation Absorbed Dose frc

Technetium-99m-Labeled Red Blood Cells

\begin{tabular}{lcc}
\hline \multirow{2}{*}{ Organ } & \multicolumn{2}{c}{ Dose, rad/mC1 } \\
\cline { 2 - 3 } & Nornal RBC & Beat-danaged-RBC \\
\hline Whole body & 0.019 & 0.018 \\
Beart & 0.078 & - \\
Spleen & 0.050 & 2.87 \\
Liver & 0.070 & 0.011 \\
Blocd & - & 0.027 \\
Lungs & 0.056 & - \\
Ridneys & 0.054 & - \\
Red marrow & 0.033 & - \\
\hline
\end{tabular}




\section{LEGENDS FOR FIGURES}

Flgure 1. Blood'clearance of indiu-111 labeled red cells in rabbit. Data fron Reference 26 , reproduced with pernission.

Flgure 2. Urine clearance of Indiu-IIl labeled red cells in rabbit. Data fron Reference 26, reproduced with pernianton.

Figure 3. An early scheme of labeling BBC with $99 \mathrm{w}^{\mathrm{T}}$ using the "pretiming" method. Date fron Reference 47, reproduced with permission.

Figure 4. An earlJ BRL schene of labeling RBC with $99 \mathrm{mTC}_{\mathrm{T}}$ using the "posi-timing" method. Data fron Reference 74, reproduced vith permission.

Flgure 5. Schewatic representation of steps involved in the currently used BhL kit method.

Figure 6. Blood clearance curves of in-vitro labeled 99mic-RBC in asplenic dog. Curve 1, saline procedure; curve 2, EDTA procedure; curve 3 , $50 \mathrm{ug} k \mathrm{kt}$, whole blood procedure; curve 4, heat-damaged RBC, saline procedure.

Figure 7. Typical imagea (right anterfor oblique, anterlor, and left anterior oblique) of the heart obtained following the administration of in-vitro labeled 99mC-RBC. Note the excellent visualization of the interventricular septum, space between the liver and heart, and the corta and pulmonary artery. Data from Reference 51, reproduced with permiaston.

Figure 8. Dynamic views of the heart obtalned ualng in-vitro labeled $99 \mathrm{~m}$ Te-RBC. Note the emptying and the filling of the heart chambers.

Figure 9. A typical gated atucy (MUGA) of the heart follouing administration of 99 m TC-RBC.

Figure 10. Change in blood concentration with time of $99 \mathrm{~m}_{\mathrm{Tc}} \mathrm{RBC}$ and $99 \mathrm{~m} \mathrm{mc-HSA}$

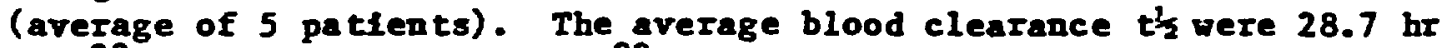

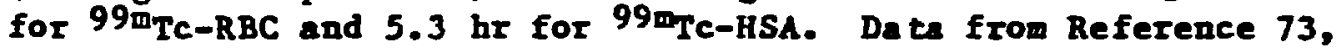
reproduced with permisaion.

Figure 11. Compariaon acintiphotos of $99 \mathrm{~m}_{\mathrm{Tc}-H S A}$ and $99 \mathrm{~m}_{\mathrm{Tc}-\mathrm{RBC}} \mathrm{distribution}$ in heart, lumg, and Ifver. Note the relative decrease in cardlac blood pool activity of 99 m TC-HSA with time and the biliamy excretion of 99m. In the $99 \mathrm{~m}$ TC-RBC atudy, the relative cardiac blood pool radioactivity remeins high compared to the liver. Date from Reference 73, reproduced with permission.

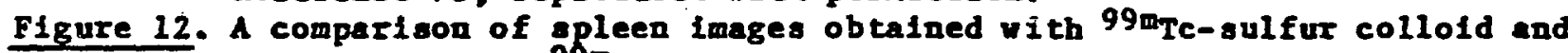
BHL-kit-labeled 99 mTC-heat damaged RBC. Note the absence of Iiver activity in the RBC image. Data from Reference 52, reproduced with permisaion. 


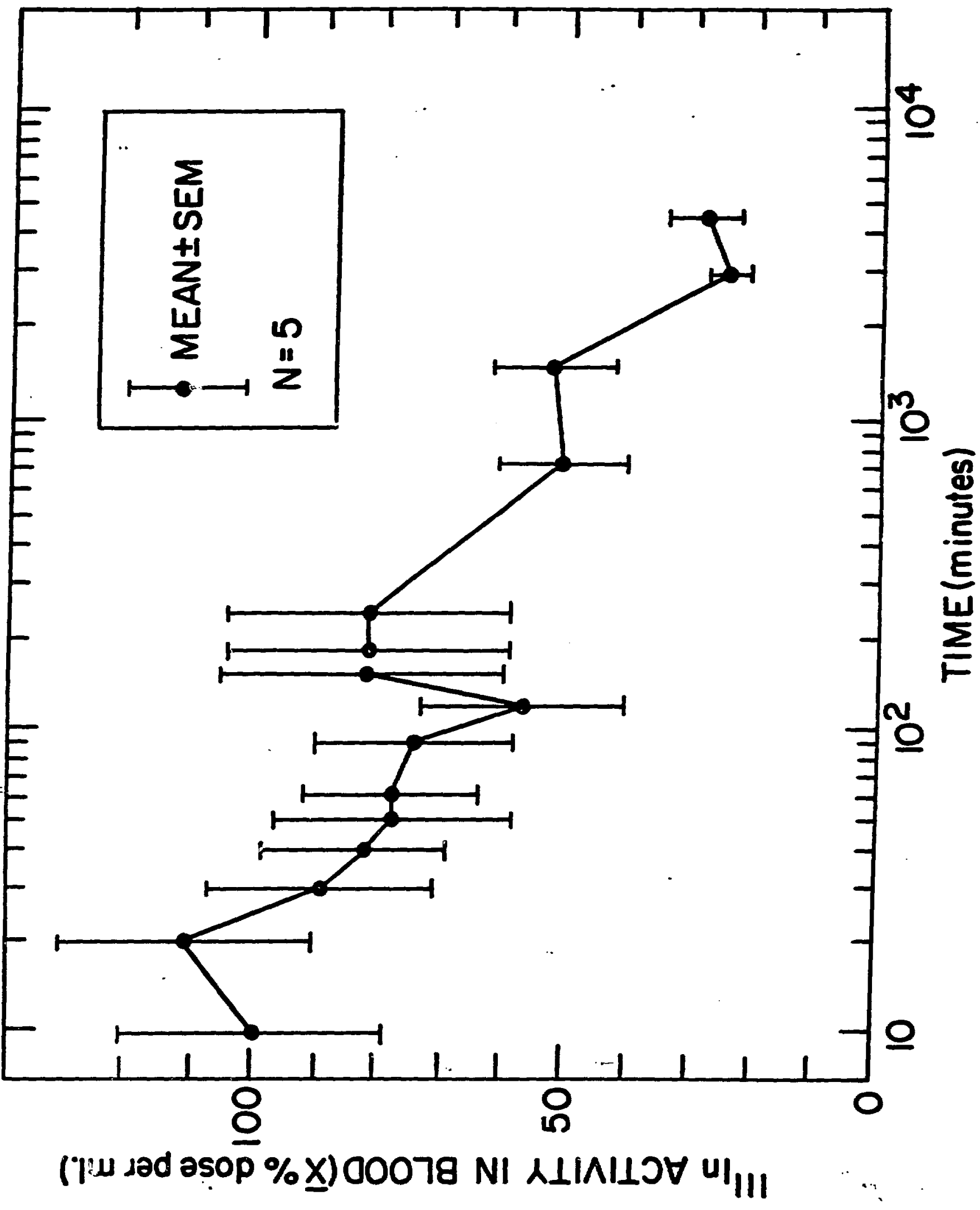




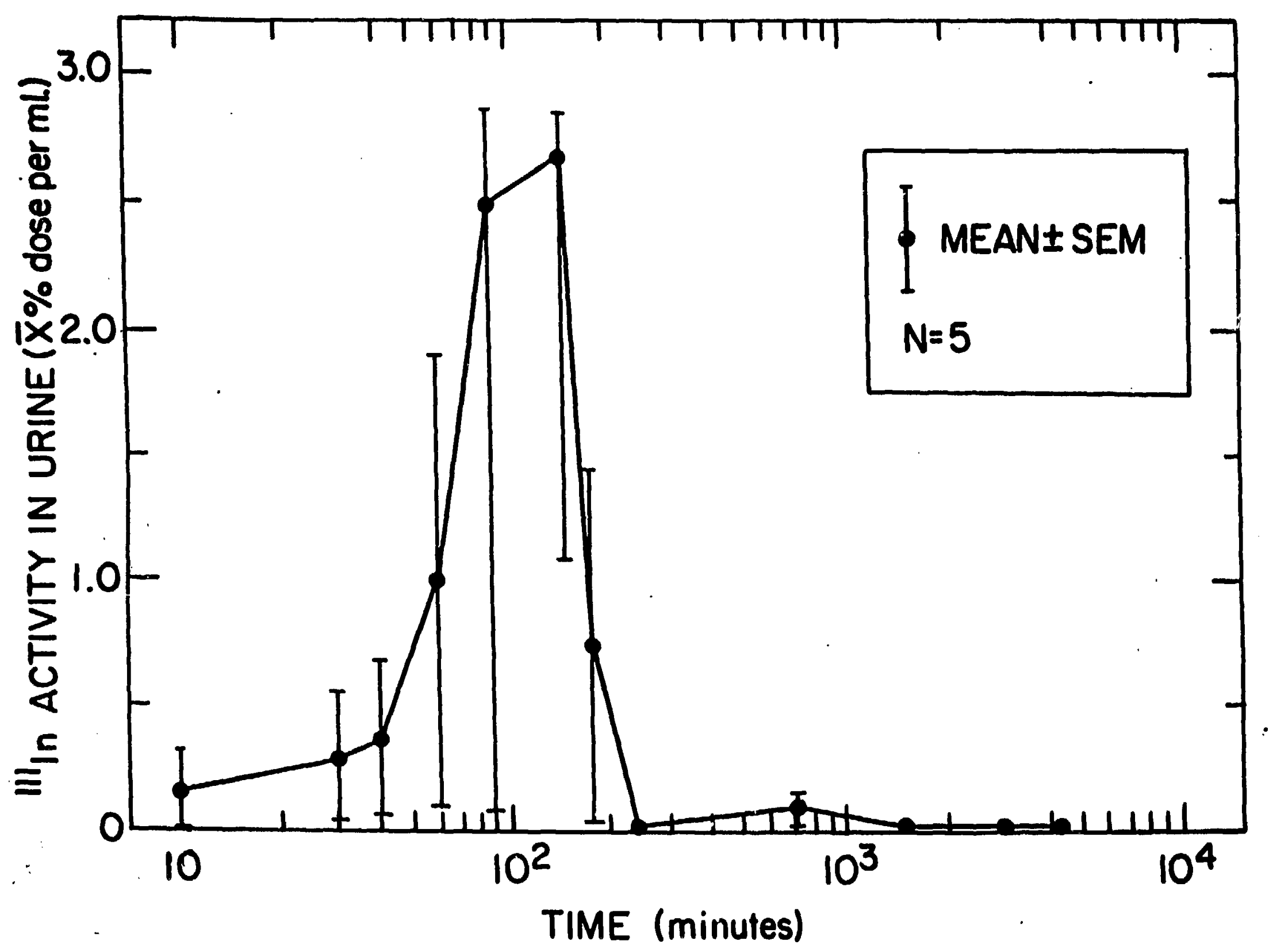




\section{(2) ADD CiHELATE}

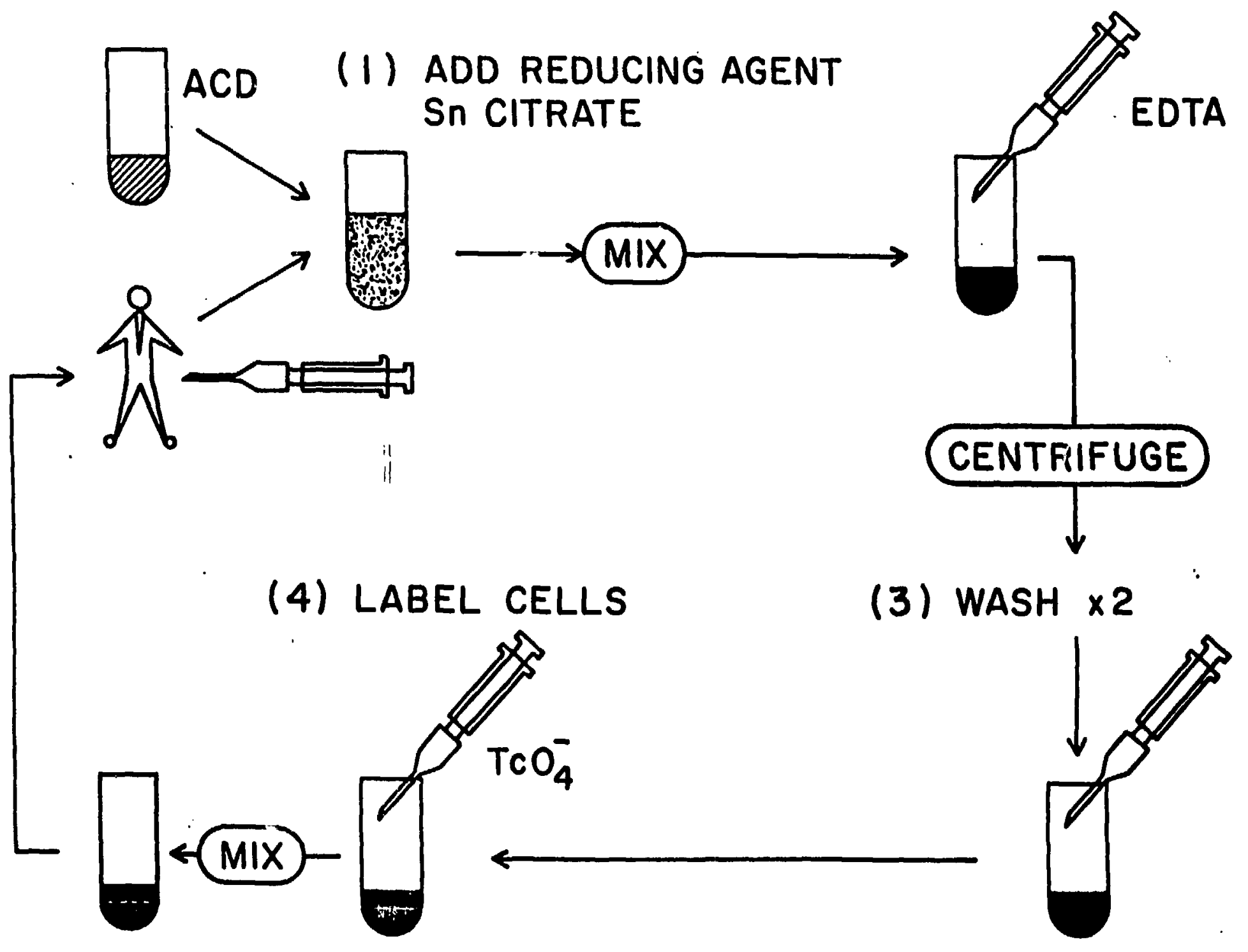




\section{(2) ADD TECHNETIUM}

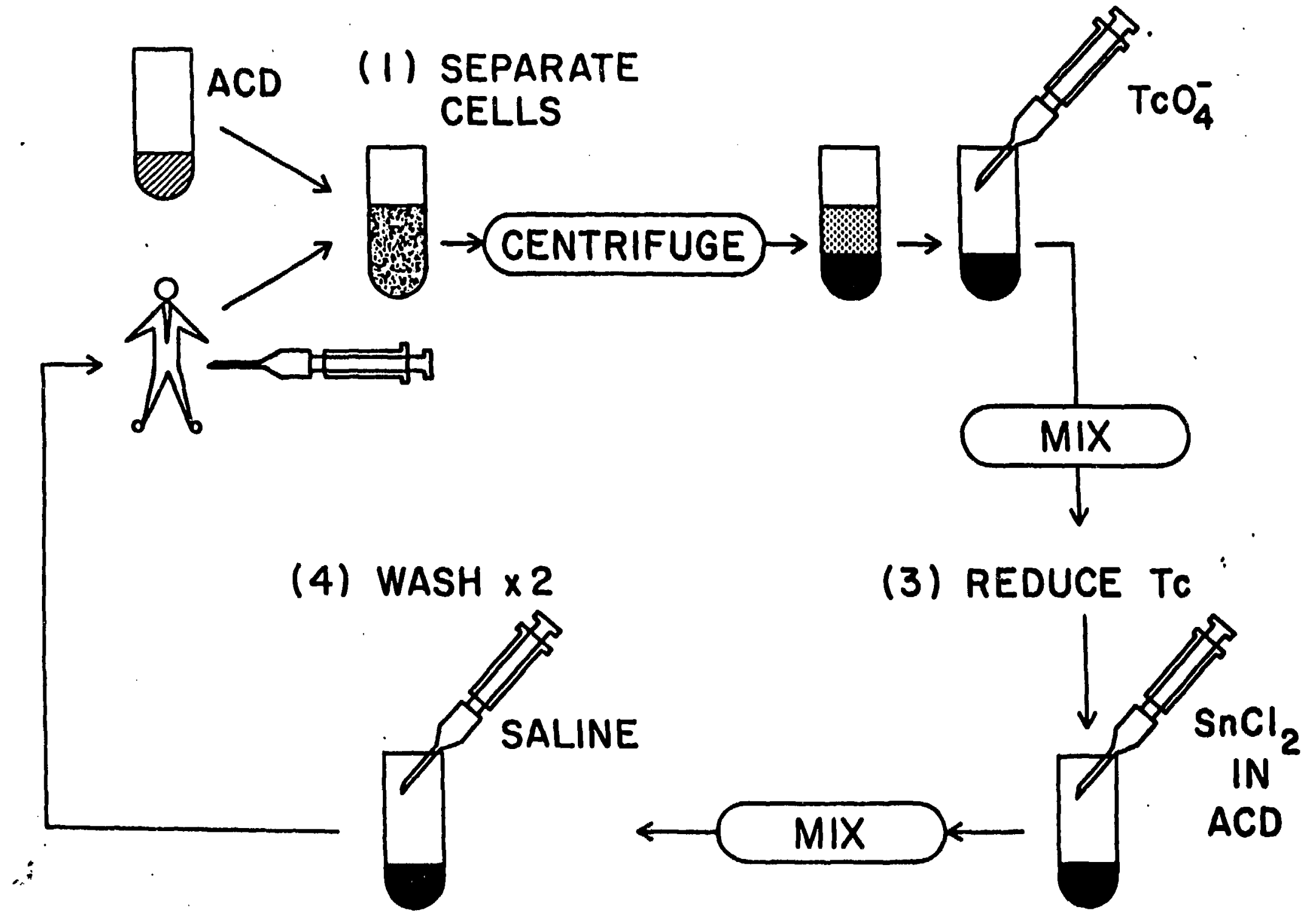




\section{BNL Kit Procedure for Preparation of ${ }^{99 \mathrm{~m}} \mathrm{Tc}$ Labeled RBC's}

Draw blood into Vacutainer kit tube

Transfer to ${ }^{99} \mathrm{TcO}_{4}$ - vial

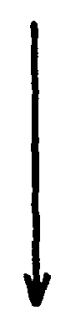

Incubate

5.10 min.
Incubate $5 \mathrm{~min}$.

Withdraw

RBC's
Add $1 \mathrm{ml} 4.4 \%$ EDTA Solution

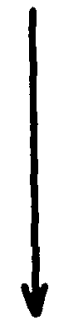

Centrifuge 


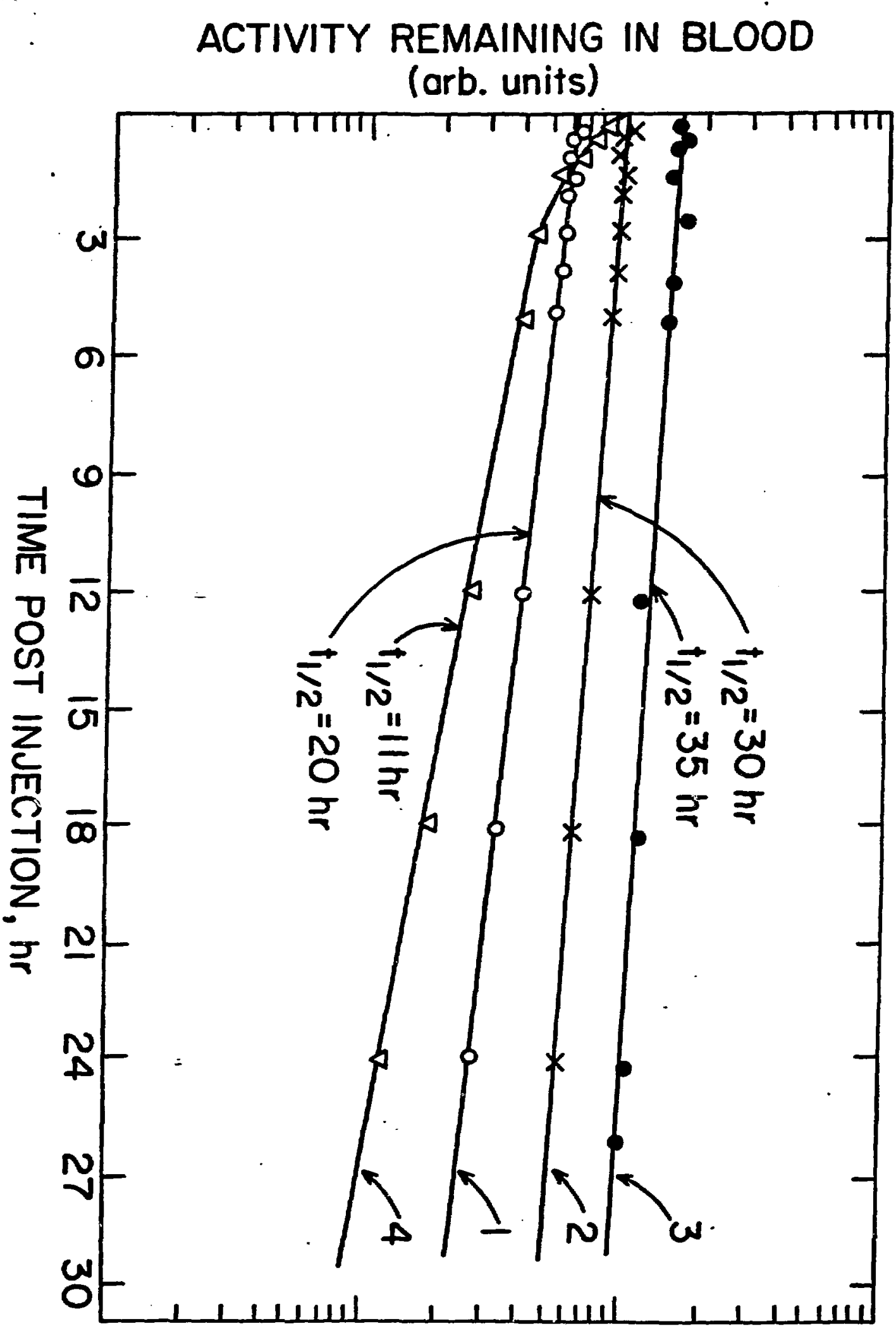



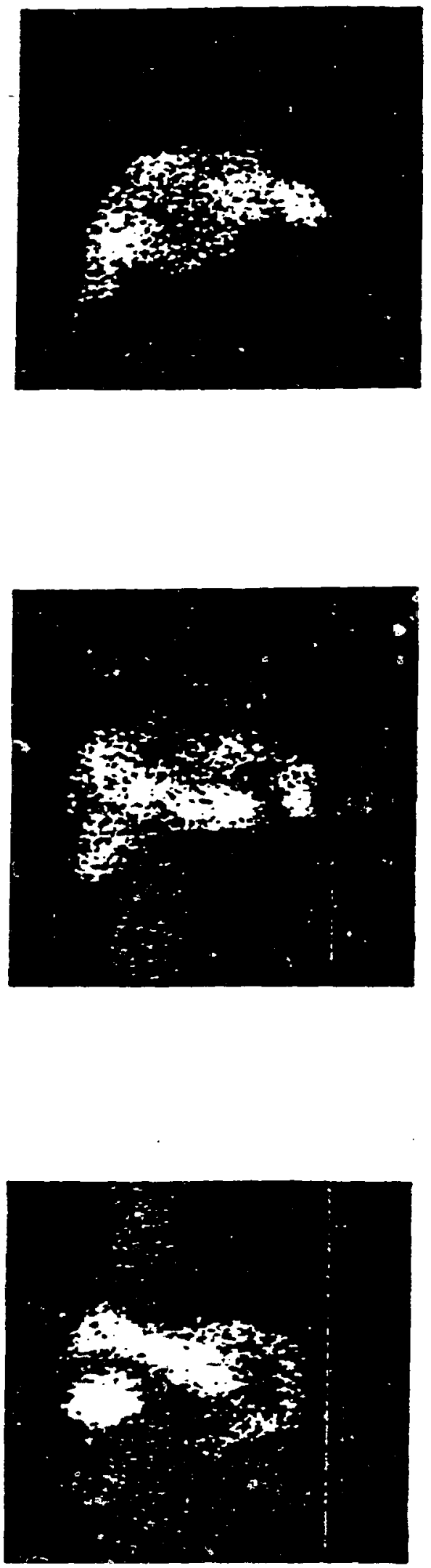

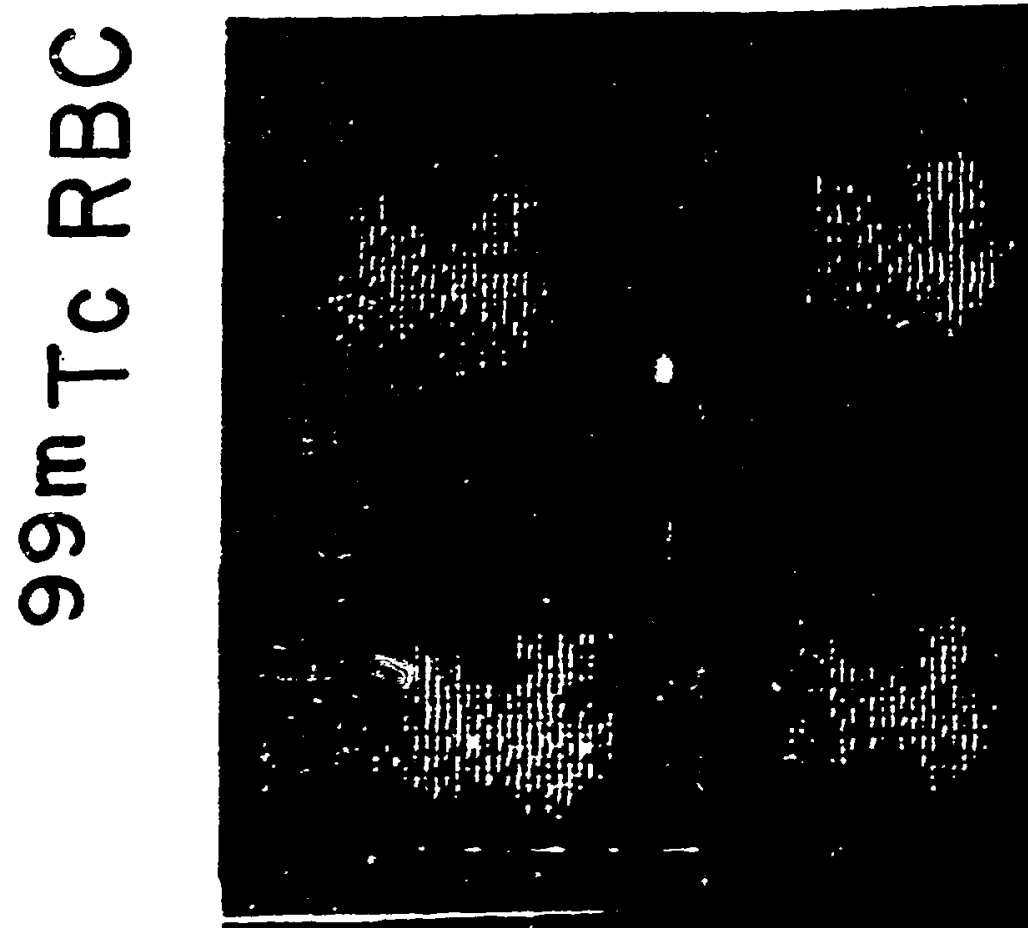

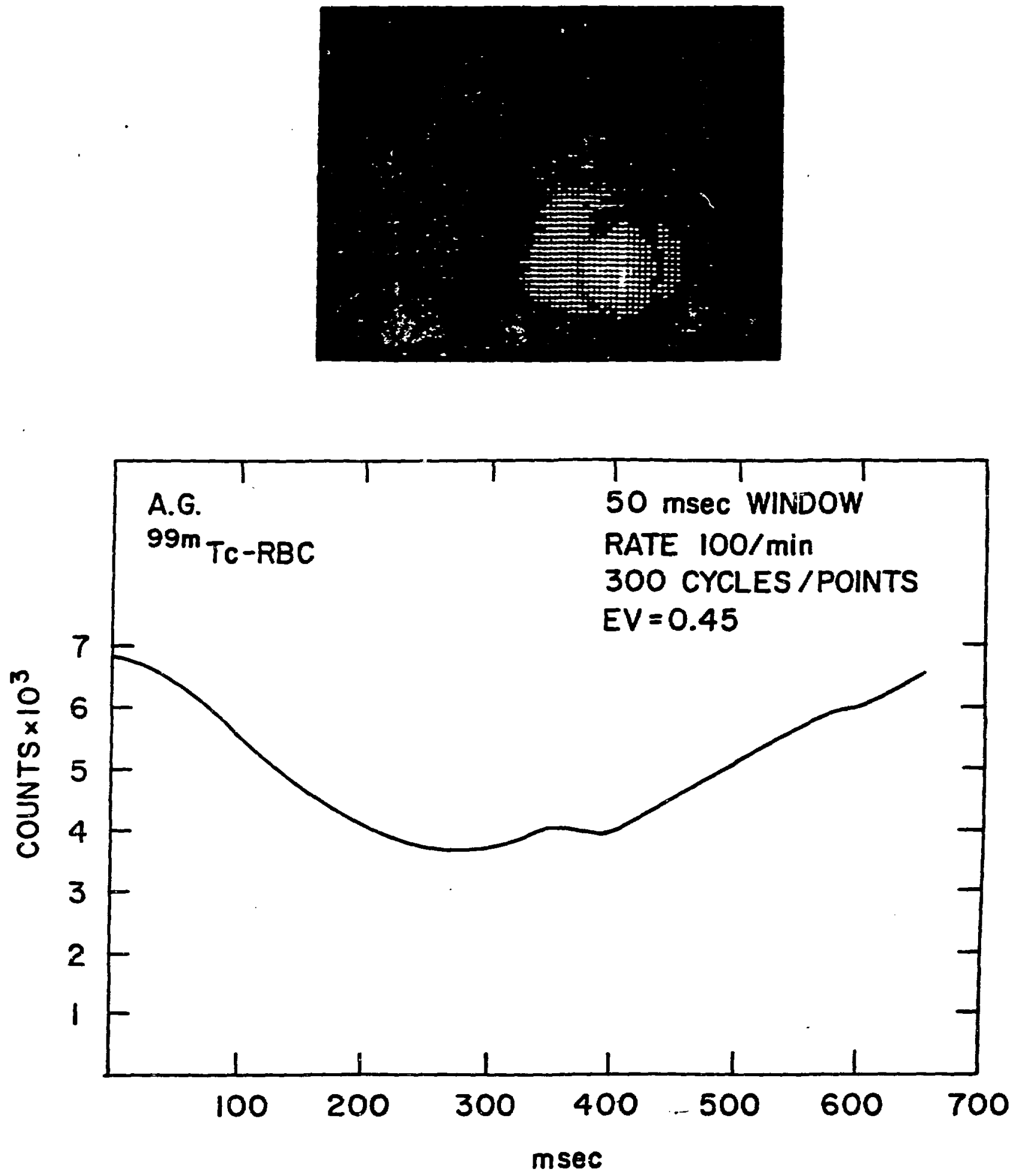


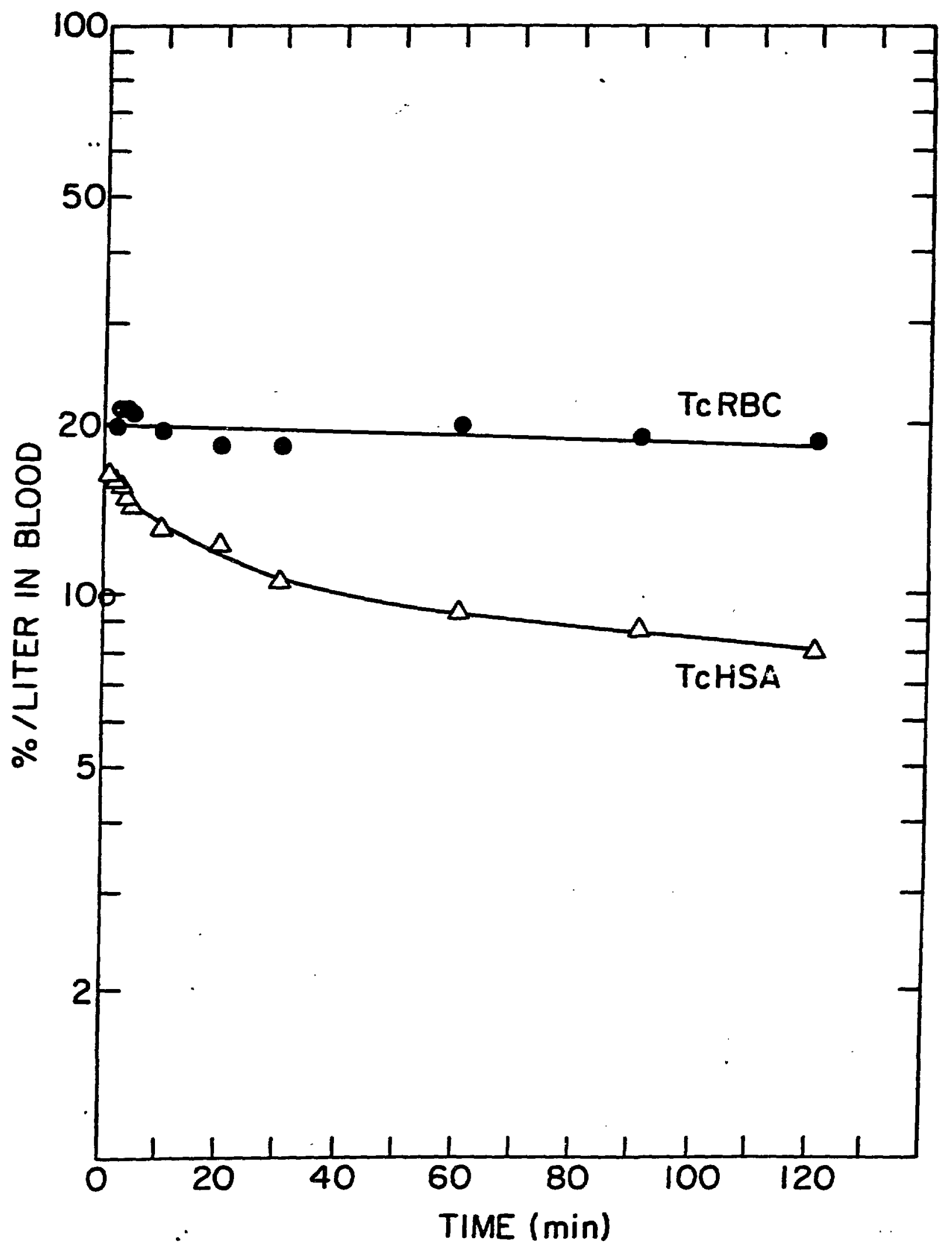




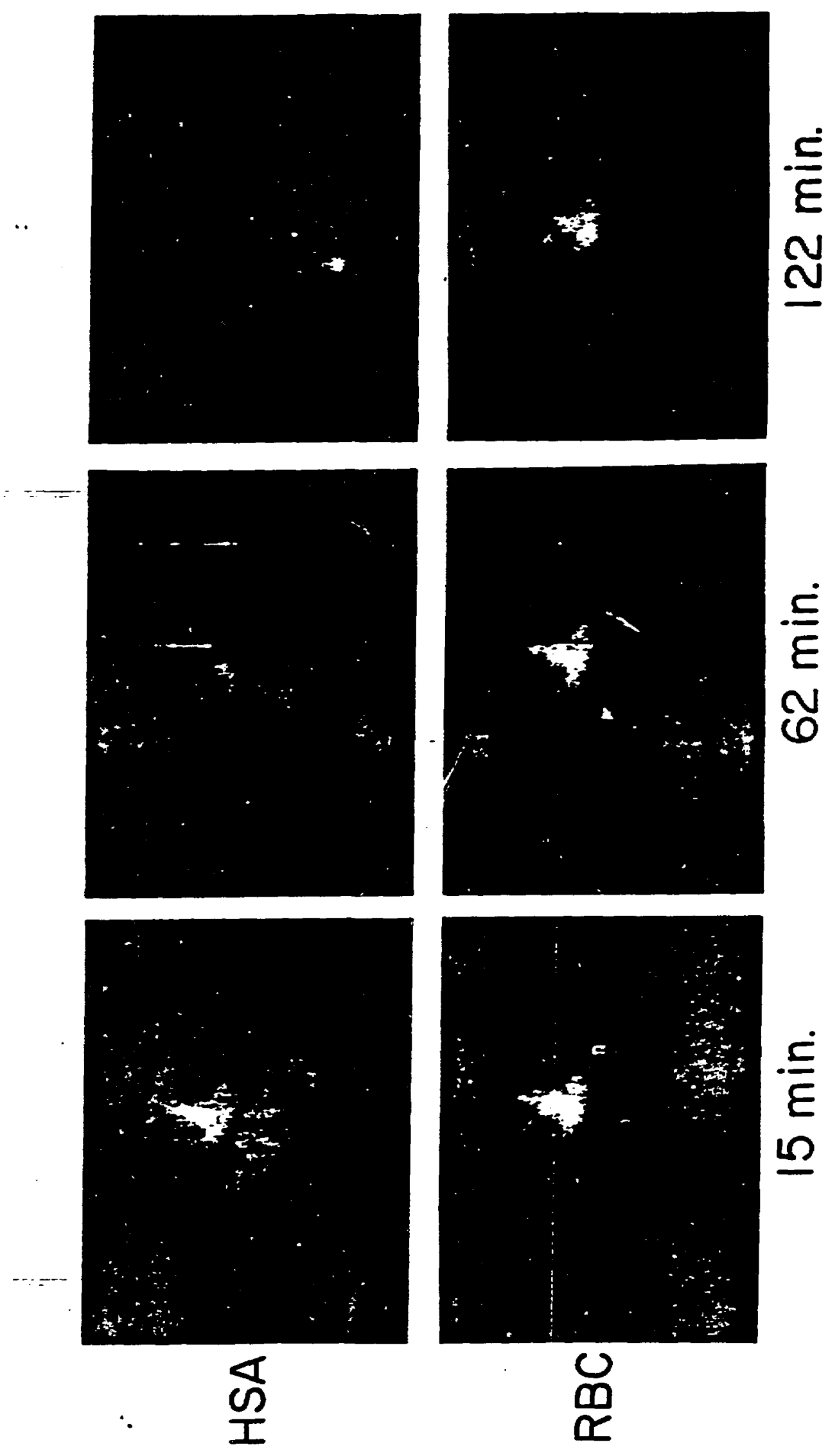




\section{R.C.}

\section{$99 \mathrm{~m}$ TcS COLLOID}

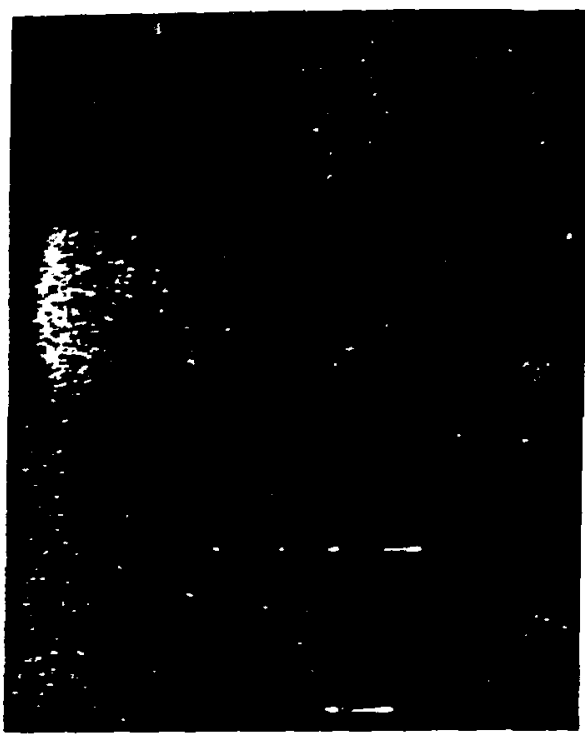

\section{ANTERIOR}
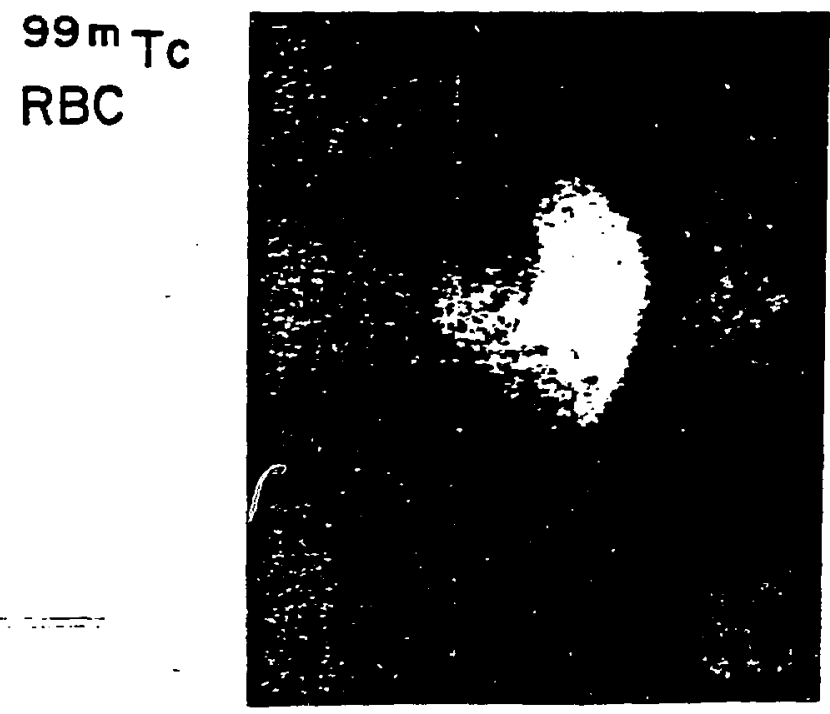

\section{.. HEPATITIS,RECOVERED}

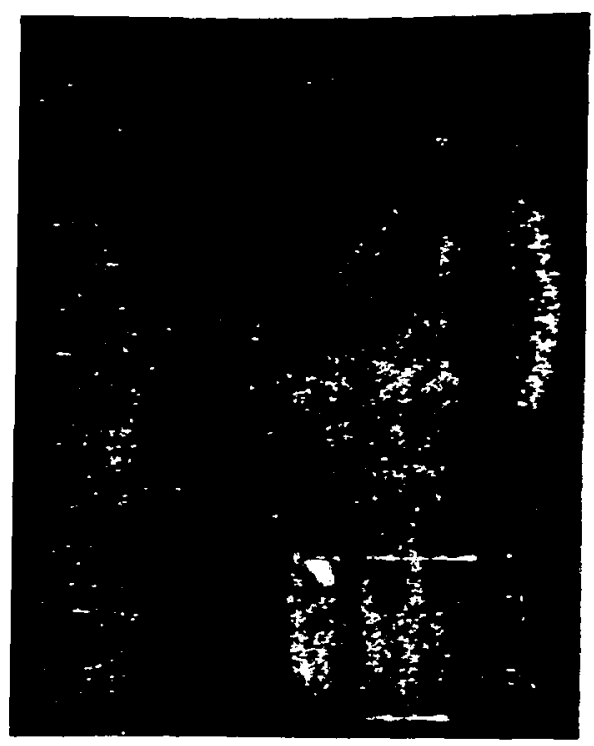

\section{POSTERIOR}

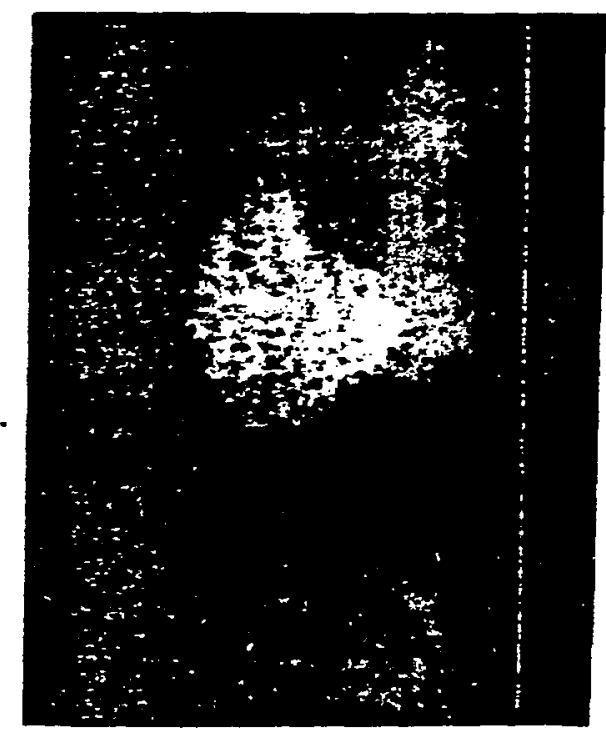

